Published in "Quaternary Science Reviews 73: 14-30, 2013"

which should be cited to refer to this work.

\title{
Cold-water coral carbonate mounds as unique palaeo-archives: the Plio-Pleistocene Challenger Mound record (NE Atlantic)
}

\author{
M. Thierens ${ }^{\mathrm{a}, *}$, E. Browning ${ }^{\mathrm{b}}$, H. Pirlet ${ }^{\mathrm{c}, 1}$, M.-F. Loutre $^{\mathrm{d}}$, B. Dorschel ${ }^{\mathrm{a}}$, V.A.I. Huvenne ${ }^{\mathrm{e}}$, \\ J. Titschack ${ }^{\mathrm{f}, \mathrm{g}}$, C. Colin $^{\mathrm{h}}$, A. Foubert ${ }^{\mathrm{i}}$, A.J. Wheeler ${ }^{\mathrm{a}}$ \\ a School of Biological, Earth and Environmental Sciences \& The Environmental Research Institute, University College Cork, Lee Road, Cork, Ireland \\ ${ }^{\mathrm{b}}$ Department of Geosciences, University of Massachusetts, Amherst, MA 01003, USA \\ ${ }^{\mathrm{C}}$ Renard Centre of Marine Geology, Department of Geology and Soil Science, Ghent University, Krijgslaan 281 s8, B-9000 Gent, Belgium \\ ${ }^{\mathrm{d}}$ Université catholique de Louvain, Chemin du Cyclotron 2 L7.01.11, 1348 Louvain-la-Neuve, Belgium \\ ${ }^{\mathrm{e}}$ Geology \& Geophysics, National Oceanography Centre, Southampton, European Way, Southampton SO14 3ZH, UK \\ ${ }_{\mathrm{f}}^{\mathrm{f}}$ MARUM, Center for Marine Environmental Sciences, University of Bremen, Leobener Str., 28359 Bremen, Germany \\ ${ }^{\mathrm{g}}$ Senckenberg am Meer, Abteilung fur Meeresforschung, Sudstrand 40, D-26382 Wilhelmshaven, Germany \\ ${ }^{\mathrm{h}}$ Laboratoire Interactions et Dynamique des Environnements de Surface (IDES, UMR8148-CNRS), Université de Paris XI, F-91405 Orsay Cedex, France \\ ${ }^{\mathrm{i}}$ Department of Geosciences - Earth Sciences, University of Fribourg, Chemin du Musée 6, CH-1700 Fribourg, Switzerland
}

Through the interplay of a stabilising cold-water coral framework and a dynamic sedimentary environment, cold-water coral carbonate mounds create distinctive centres of bio-geological accumulation in often complex (continental margin) settings. The IODP Expedition 307 drilling of the Challenger Mound (eastern Porcupine Seabight; NE Atlantic) not only retrieved the first complete developmental history of a coral carbonate mound, it also exposed a unique, Early-Pleistocene sedimentary sequence of exceptional resolution along the mid-latitudinal NE Atlantic margin.

In this study, a comprehensive assessment of the Challenger Mound as an archive of Quaternary palaeo-environmental change and long-term coral carbonate mound development is presented. New and existing environmental proxy records, including clay mineralogy, planktonic foraminifer and calcareous nannofossil biostratigraphy and assemblage counts, planktonic foraminifer oxygen isotopes and siliciclastic particle-size, are thereby discussed within a refined chronostratigraphic and climatic context.

Overall, the development of the Challenger Mound shows a strong affinity to the Plio-Pleistocene evolution of the Northern Hemisphere climate system, albeit not being completely in phase with it. The two major oceanographic and climatic transitions of the Plio-Pleistocene - the Late Pliocene/Early Pleistocene intensification of continental ice-sheet development and the mid-Pleistocene transition to the more extremely variable and more extensively glaciated late Quaternary - mark two major thresholds in Challenger Mound development: its Late Pliocene ( $>2.74 \mathrm{Ma}$ ) origin and its Middle-Late Pleistocene to recent decline. Distinct surface-water perturbations (i.e. water-mass/polar front migrations, productivity changes, melt-water pulses) are identified throughout the sequence, which can be linked to the intensity and extent of ice development on the nearby British-Irish Isles since the earliest Pleistocene. Glaciation-induced shifts in surfacewater primary productivity are thereby proposed to fundamentally control cold-water coral growth, which in turn influences on-mound sediment accumulation and, hence, coral carbonate mound development throughout the Pleistocene. As local factors, such as proximal ice-sheet dynamics and on-mound changes in cold-water coral density, significantly affected the development of the Challenger Mound, they can potentially explain the nature of its palaeo-record and its offsets with the periodicities of global climate variability. On the other hand, owing to this unique setting, a regionally exceptional, high-resolution palaeo-record of Early Pleistocene (ca 2.6 to $2.1 \mathrm{Ma}$ ) environmental change (including early British-Irish ice-sheet development), broadly in phase with the 41 ka-paced global climate system, is preserved in the lower Challenger Mound. All in all, the Challenger Mound record highlights the wider relevance of coral carbonate mound archives and their potential to capture unique records from dynamic (continental margin) environments.

\footnotetext{
* Corresponding author. Present address: Lamont-Doherty Earth Observatory, P.O. Box 1000, 61 Route 9W, Palisades, NY 10964, USA. E-mail address: mieke.thierens@gmail.com (M. Thierens).

1 Present address: Flanders Marine Institute - VLIZ, Innovocean Site, Wandelaarkaai 7, B-8400 Oostende, Belgium.
} 


\section{Introduction}

Along the NE Atlantic continental shelves and slopes reef framework-forming cold-water coral ecosystems (dominated by Lophelia pertusa and Madrepora oculata) are found to successfully mediate sediment accumulation and, hence, facilitate the build-up of so-called 'coral carbonate mounds' (sensu Roberts et al., 2009) (Fig. 1). During the past two decades, a vast amount of research has been conducted on these 'European' mounds, not in the least to constrain the environmental conditions that favour cold-water coral growth and mound development at intermediate water depths (see Section 2.2.2). In addition, both cold-water coral fragments and mound matrix sediments (i.e. the hemipelagic sediments that accumulate in between the coral branches; see e.g. Roberts et al., 2009) have been tested as recorders of past environmental conditions. Although not without its problems, coldwater corals have been used to reconstruct, for example, past seawater temperatures (e.g. Lutringer et al., 2005; Sherwood et al., 2005; Rüggeberg et al., 2008), ocean ventilation (e.g. Adkins et al., 1998; Frank et al., 2004) and ocean circulation (e.g. Colin et al., 2010; Copard et al., 2010, 2012). Similarly, sediment sequences from piston and gravity cores through sub-recent mound units have been analysed to infer late Quaternary palaeo-environmental conditions along the NW European continental margin (e.g. Rüggeberg et al., 2007; Wienberg et al., 2010; Pirlet et al., 2011). However, the fragmented nature and low resolution of late Quaternary mound sequences, rich in hiati known to span up to several hundred thousand years (e.g. Dorschel et al., 2005; Eisele et al., 2008; Mienis et al., 2009b), challenges their potential as highresolution palaeo-archives.

The IODP Expedition 307 drilling of the Challenger Mound (Belgica mound province, east Porcupine Seabight) (Fig. 1) offers a new perspective. Not only did it recover the first complete sequence through a coral carbonate mound (documenting mound initiation till decline; Ferdelman et al., 2006), the $155 \mathrm{~m}$ long Pleistocene-Holocene Challenger Mound cores also exposed a ca $132 \mathrm{~m}$ long, semi-continuous Early Pleistocene (2.6-1.7 Ma) record of alternating current-influenced and ice-rafted deposits from the mid-latitudinal NE Atlantic margin (Thierens et al., 2010). Considering the dynamic, erosive/non-depositional environment established along the NW European continental margin during the Early Pleistocene (e.g. Laberg et al., 2005; Huvenne et al., 2009b), the preservation of such a high-resolution sequence is exceptional and provides a unique opportunity to study Early Pleistocene regional climate change. As such, the Challenger Mound ice-rafted detritus record has proven crucial in elucidating the long-term history and early development of ice on the British-Irish Isles, ca 2 Ma earlier than previously assumed (Thierens et al., 2012). Similarly, the sedimentological, geochemical and geophysical analysis of basal Challenger Mound deposits has, for the first time, shed light on the palaeo-environmental drivers behind mound initiation and early mound development (Kano et al., 2007; Foubert and Henriet, 2009; Huvenne et al., 2009b; Sakai et al., 2009; Titschack et al., 2009; Thierens et al., 2010; Raddatz et al., 2011). However, a quantitative assessment of the Challenger Mound as archive of Quaternary palaeo-environmental change along the NE Atlantic margin is at present still lacking.

To address this issue, this study aims to quantify and assess the palaeo-environmental signal recorded in the entire IODP Exp. 307 Hole U1317E Challenger Mound sedimentary sequence (i.e. top to mound base) in a global chronostratigraphic and climatic context. In order to do so, a new, comprehensive Hole U1317E sediment chronostratigraphy is first presented. Within this revised chronostratigraphic framework, new (clay mineralogy, planktonic foraminifer and calcareous nannofossil assemblages) and existing (planktonic foraminifer stable oxygen isotopes, matrix carbonate content, siliciclastic particle-size) environmental proxy records will be evaluated, with implications for the Challenger Mound record as archive of (1) long-term coral carbonate mound development and (2) North-Atlantic Plio-Pleistocene environmental variability.

\section{General setting}

\subsection{Porcupine Seabight}

The Porcupine Seabight is a shallow to deep-water (250 to $>3000 \mathrm{~m}$ ), north-south trending embayment in the Irish sector of the northeast Atlantic continental margin (Fig. 1). Formed as a failed-rift basin during the opening of the North Atlantic, its Neogene post-rift sedimentary history alternates contourite drift deposition with several regional erosion events (Van Rooij et al., 2003; Stoker et al., 2005; Shannon et al., 2007) (Fig. 1).

Along the margins of the Porcupine Seabight, cold-water coral carbonate mounds are found at intermediate water depth, clustered together into four well-defined provinces between ca 450 and 1000 m water depth (De Mol et al., 2002; Huvenne et al., 2007; Van Rooij et al., 2009; Dorschel et al., 2010) (see Fig. 1). At present, the hydrography in this depth range is influenced by Eastern North Atlantic Water (ENAW; 0-800 m) and Mediterranean Outflow Water (MOW; 800-1100 m), which both flow northwards along the continental margin (Rice et al., 1991; New et al., 2001; White, 2007) (Fig. 1). The benthic environment along the eastern slopes of the Porcupine Seabight is influenced by the interplay of a north-west directed (along-slope) residual current with across-slope diurnal tidal motions (Dorschel et al., 2007; White, 2007; White et al., 2007). Maximum current intensification thereby occurs at the depth of the permanent thermo- and pycnocline, which is present at the transition between ENAW and MOW (ca 600-800 m water depth) (White, 2007; White and Dorschel, 2010).

Besides (along-slope) bottom-current action, Pleistocene icesheet development seems to have significantly affected sediment deposition in Porcupine Seabight (e.g. Peck et al., 2007; Van Rooij et al., 2007; Thierens et al., 2012). Although some influence from more far-field circum-Atlantic ice sheets is recorded in the area, icerafted detritus layers mainly attest to the dynamic nature of the nearby British-Irish Ice Sheet (Peck et al., 2007; Scourse et al., 2009; Thierens et al., 2012) (Fig. 1).

\subsection{Cold-water coral carbonate mounds}

\subsubsection{The Challenger coral carbonate mound}

As part of the Belgica mound province, the Challenger Mound is one of the 44 exposed cold-water coral carbonate mounds rooted between 659 and $1065 \mathrm{~m}$ water depth on the eastern slope of the Porcupine Seabight (Fig. 1) (Dorschel et al., 2010). Challenger Mound has an elongated shape, measuring ca $155 \mathrm{~m}$ high and covering ca $0.55 \mathrm{~km}^{2}$ at its base (De Mol et al., 2002).

During IODP Expedition 307, several sedimentary records were recovered from the Challenger Mound (Holes U1317A-E), including a ca $155 \mathrm{~m}$ long complete mound sequence from its summit (Hole U1317E). Fragments of the cold-water coral species L. pertusa (and in lesser quantities $M$. oculata) have been identified throughout the entire mound sequence, which consists of unlithified silty coral floatstone-rudstone, bafflestone and, to a lesser degree, wackestone facies (Ferdelman et al., 2006). Siliciclastic (terrigenous) grains represent between 18 and 88 wt.\% of the (non-coral) matrix sediment (Fig. 2) and are dominated by quartz (mean: 50 wt.\%), feldspar (mean: 13 wt.\%) and clay minerals (mean: 40 wt.\%) (Titschack et al., 2009; Thierens et al., 2010). The (non-coral) carbonate fraction of the matrix sediment consists predominantly of biogenic calcite 


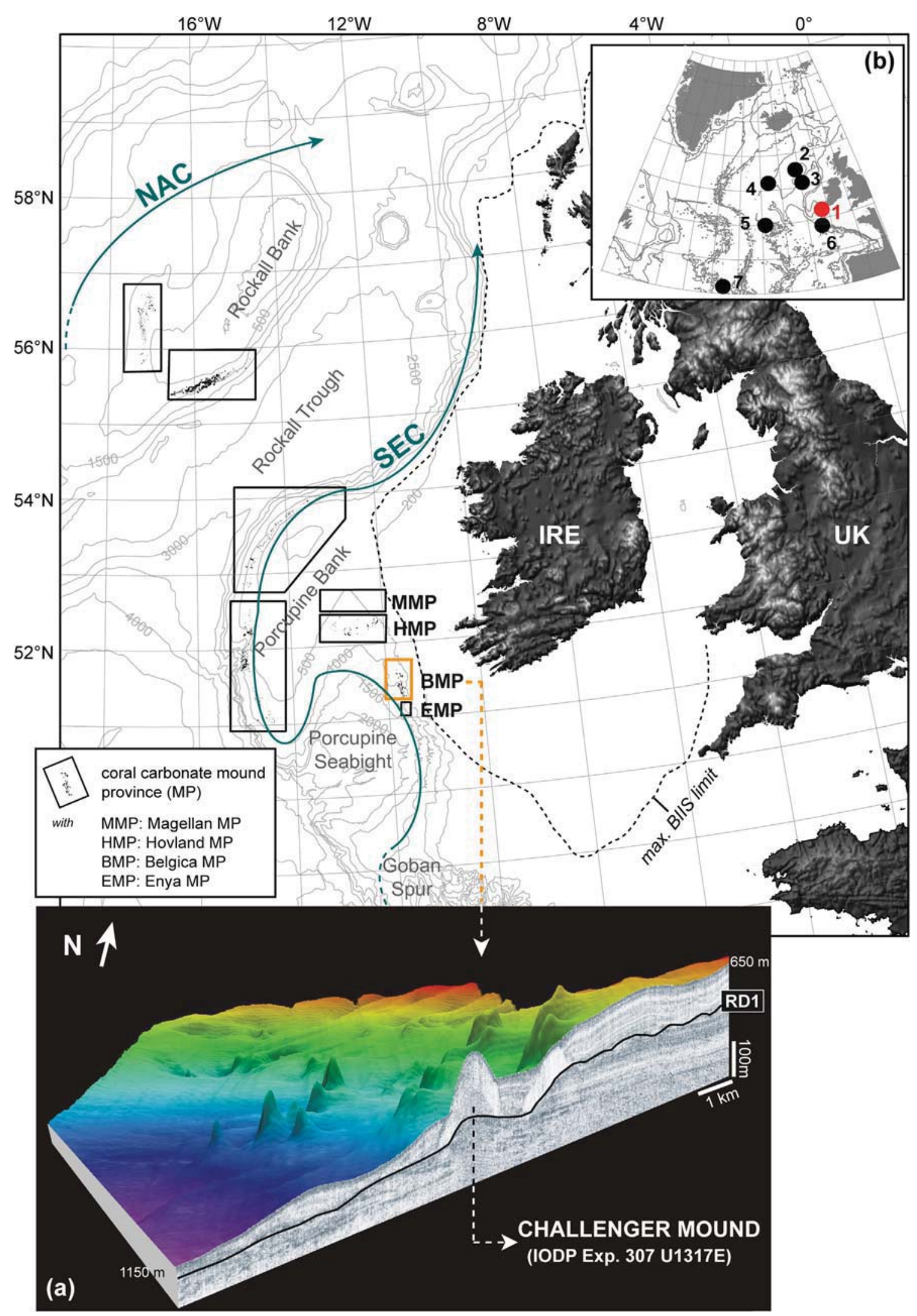

Fig. 1. Location of the Challenger cold-water coral carbonate mound (IODP. Exp. 307 Hole U1317E) on the eastern continental margin of the Porcupine Seabight (NE Atlantic). Coral carbonate mound provinces (MP) along the Irish margin are indicated (adapted from Dorschel et al. 2010). Inset (a): Multibeam bathymetry - seismic reflection profile of the Belgica MP visualising the position of the Challenger Mound and its relation to the 'RD1' regional unconformity (modified after Van Rooij et al., 2003; Pirlet et al., 2011). Inset (b): Location of IODP 1317 (1), ODP 982 (2), ODP 981 (3), DSDP 552 (4), IODP 1308/DSDP 609 (5), DSDP 548 (6) and DSDP 607 sites, for further reference (see text). Blue arrows show the present-day path of the North Atlantic Current (NAC) and Shelf Edge Current (SEC) (after Hansen and Østerhus, 2000); the black dashed line represents the maximum extent of the last British-Irish Ice Sheet (BIIS; after Scourse et al., 2009). (For interpretation of the references to colour in this figure legend, the reader is referred to the web version of this article.) 
derived from foraminifers and calcareous nannoplankton (Titschack et al., 2009).

At the mound base, no hardground, but a firmground of unlithified glauconitic siltstones was recovered (Ferdelman et al., 2006), marking the Late Miocene-Late Pliocene regional unconformity ('RD1' Van Rooij et al., 2003, 2009; 'C10' Stoker et al., 2005 ) that underlies all coral carbonate mounds in the Porcupine Seabight (De Mol et al., 2002) (Fig. 1). Previous stratigraphic work generally agrees on a Holocene to Early Pleistocene/Late Pliocene age for the Hole U1317E Challenger Mound sequence (see Supplementary Materials for more details). A significant intra-mound unconformity ('mound crisis': ca 1. 67-1.03 Ma; Kano et al., 2007) separates the Middle-Late Pleistocene to Holocene upper mound sequence (unit M2; 23.5-0 corrected metres below seafloor [mbsf]) from the Early Pleistocene/Late Pliocene lower mound sequence (unit M1; 155.2-23.5 mbsf). This unconformity might be related to the $1.2-0.65 \mathrm{Ma}$ midPleistocene climate transition (Foubert and Henriet, 2009; Huvenne et al., 2009b; Sakai et al., 2009; Titschack et al., 2009; Thierens et al., 2010).

Also sedimentologically, the upper (M2) and lower (M1) mound units are distinctly different. Whereas unit M1 bears witness of a semi-continuous, fast accumulating and current-controlled depositional environment, the condensed/fragmented unit M2, on the other hand, reveals a clear switch to a more glacially-influenced, low accumulation setting (see details in Thierens et al. (2010)). Throughout the mound sequence, siliciclastic sediments are deposited either by bottom currents, operating in variable energetic modes, or by iceberg rafting. A total of 27 ice-rafted detritus (IRD) intervals have been identified in the Challenger Mound record, including a series of 16 distinct IRD horizons in unit M1 (Thierens et al., 2010, 2012). Radiogenic isotope provenance fingerprinting clearly relates these events to the waxing and waning of an ice sheet on the islands of Britain and Ireland, both in the Middle-Late (unit M2) as well as Early Pleistocene (unit M1) (Thierens et al., 2012).

\subsubsection{Cold-water coral carbonate mound development}

In recent years, the definite influence of local environmental factors on coral carbonate mound development has been strongly evidenced. By controlling water-mass properties such as temperature, salinity and oxygen levels as well as the availability of food (i.e. labile organic matter) and sediment particles, the local hydrographic and near-bed hydrodynamic setting defines the success of cold-water coral growth and, therefore, of mound development (e.g. De Mol et al., 2002; Freiwald et al., 2004; Roberts et al., 2006, 2009; Dorschel et al., 2007; Duineveld et al., 2007; Foubert et al., 2007; Mienis et al., 2007, 2009a, 2012; Rüggeberg et al., 2007; Wheeler et al., 2007, 2008; Dullo et al., 2008; Davies et al., 2009; Huvenne et al., 2009a,b; 2011; Thierens et al., 2010; White and Dorschel, 2010; Wienberg et al., 2010; Pirlet et al., 2011).

At the Irish Atlantic continental margin, successful coral carbonate mound build-up has been primarily associated with highly energetic hydrodynamic conditions and the presence and positioning of water-mass boundaries at intermediate water depths. The dynamic environment at water-mass boundaries is believed to be optimal for both cold-water coral growth and on-mound sediment accumulation, through the (maximum) enhancement of bottom currents, the concentration of nutrient particles and the large across-slope movement of sediments (e.g. White and Dorschel, 2010). Hence, climatically-induced hydrodynamic changes - and late Quaternary glacial-interglacial fluctuations in bottom-current regime and water-column stratification in particular - are considered to govern recent coral carbonate mound development along the Irish Atlantic margin (e.g. Dorschel et al., 2005; Foubert et al., 2007; Rüggeberg et al., 2007; de Haas et al., 2009; Mienis et al., 2009b; White and Dorschel, 2010; Pirlet et al., 2011). In this context, the presence, position and highly-energetic flow of MOW during Late Pleistocene and Holocene interglacial/ interstadial periods is often used to explain the success of coral carbonate mound growth in the Porcupine Seabight during these 'warm' periods (e.g. De Mol et al., 2002; Dorschel et al., 2005; Kano et al., 2007; Rüggeberg et al., 2007; Sakai et al., 2009; Titschack et al., 2009; Raddatz et al., 2011).

Distinctly different patterns of coral (mound) growth in different parts of the $\mathrm{N}$ Atlantic illustrate the impact of specific local environmental factors on coral carbonate mound development (see overviews in e.g. Roberts et al., 2009; Frank et al., 2011; López Correa et al., 2012) However, north-south movements of cold nutrient-rich intermediate water masses as well as the Polar Front, have recently been proposed as large-scale drivers of late Quaternary cold-water coral reef build-up throughout the NE Atlantic (Frank et al., 2011).

\section{Materials and methods}

All sediments analysed in this study were recovered during the IODP Exp. 307 (Hole U1317E) drilling of the Challenger coral carbonate mound $\left(51^{\circ} 22.8^{\prime} \mathrm{N}, 11^{\circ} 43.1^{\prime} \mathrm{W} ; 792.2 \mathrm{~m}\right.$ water depth) (Ferdelman et al., 2006). Core depths are corrected for decompaction and reported as 'corrected metre below seafloor' (mbsf).

\subsection{Calcareous plankton assemblages}

\subsubsection{Calcareous nannofossils}

A total of 92 samples from core U1317E, collected at variable sampling intervals throughout the Challenger Mound sequence (0.68-155.09 mbsf), were selected for calcareous nannofossil biostratigraphic analysis. Smear slides were prepared using the method of Watkins and Bergen (2003) and examined under a crosspolarised transmitted light microscope (1250 times magnification). Per sample, species abundance counts were generated by counting the total number of each species in twenty fields of view (FOV). Long traverses of the slides were analysed to quantify rare taxa. The first occurrence (FO), last occurrence (LO) and first consistent occurrence (FCO) of species are used to define U1317E nannofossil datum levels, which are then related to the calcareous nannofossil biostratigraphic events reported by Raffi et al. (2006) (Atlantic ODP Sites 925 and 926), de Kaenel et al. (1999) (Mediterranean ODP Sites 974, 977 and 979) and Sato et al. (2004) (Atlantic DSDP Sites 608, 609 and 611).

Besides biostratigraphy, nannofossil assemblages are compiled to complement palaeo-environmental planktonic foraminifer assemblage counts, especially around the unit M1 - unit M2 transition (see Section 6.3). Species with a specific affinity towards more or less nutrient-rich conditions are used to create a nannofossil palaeo-productivity indicator (NP-index; see Section 4.1.3) Quantitative nannofossil species abundances (\%) were obtained for 36 samples in the interval between 0.68 and 51.77 mbsf $(1.5 \mathrm{~m}$ average sampling interval). Population counts were generated by counting 456 specimens per sample, assuring a 95\% confidence interval (cf. Chang, 1967). Gephyrocapsids are classified according to the taxonomic concepts of Bollmann (1997), Baumann and Freitag (2004) and Flores and Marino (2002). Gephyrocapsa caribbeanica includes gephyrocapsids between 3 and $4 \mu \mathrm{m}$ in size, with closed central areas and low angle bridge $\left(<40^{\circ}\right)$. 'Small G. caribbeanica' includes all morphotypes smaller than $3 \mu \mathrm{m}$. In this study, G. caribbeanica ( $>4 \mu \mathrm{m}$ ) occurs rarely and was only evaluated for its biostratigraphic range. 


\subsubsection{Planktonic foraminifers}

Full planktonic foraminiferal assemblage counts were carried out on a sub-set of 52 samples. Sampling intervals vary from 0.2 to $23.8 \mathrm{~m}$, as samples were specifically selected for two purposes: (1) to representatively cover the full range of palaeo-environmental conditions throughout the Challenger Mound depositional sequence, and (2) to develop a biostratigraphic framework for the Hole U1317E mound cores. Sample selection for (1) is based on the different sediment facies and transitions characterised by Thierens et al. (2010).

In all samples, the fraction $>150 \mu \mathrm{m}$ was sieved off, dried and then split until a representative sub-assemblage of ca 300 to 600 planktonic specimen was obtained. Planktonic foraminifers were identified following the taxonomic descriptions by Kennett and Srinivasan (1983). Per sample, a record of the full faunal assemblage, including a minimum of 300 Neogloboquadrina pachyderma specimens ( sinistral (s) and dextral (d)), and the associated amount of lithic grains was kept. In this way, the relative abundance (\%) of planktonic species, of $N$. pachyderma s with respect to the total number of $N$. pachyderma specimen and of planktonic foraminifers versus lithic grains in the coarse $(>150 \mu \mathrm{m})$ sediment fraction could be calculated. Species with a specific affinity towards more or less nutrient-rich conditions are used to create a planktonic foraminifer palaeo-productivity indicator (FP-index; see Section 4.1.3). Foraminifer preservation (well - moderate - poor - very poor) is described with special reference to secondary (diagenetic) carbonate encrustration. Sample recounts of five samples indicate an average absolute error of ca $5 \%$ on species abundances (\%). Planktonic foraminifer biostratigraphic datums are derived from the North Atlantic temperate/sub-polar zonation scheme by Weaver and Clement (1986).

\subsection{Clay mineralogy}

The mineral assemblage of the carbonate-free clay-sized $(<2 \mu \mathrm{m})$ sediment fraction of 141 samples was quantified by means of X-ray diffraction (XRD) analysis. Samples were taken at 0.1-2 m sampling intervals to representatively characterise different sediment facies (sensu Thierens et al., 2010) throughout the entire Challenger Mound sequence. Clay minerals were identified using a PANalytical diffractometer ( $\mathrm{Cu}-\mathrm{K} \alpha$ radiation source) at the IDES laboratory (University of Paris XI) on oriented mounts of noncalcareous clay-sized $(<2 \mu \mathrm{m})$ particles. The oriented mounts were obtained following the methods described in detail by Liu et al. (2004). Three XRD runs were performed, following air-drying, ethylene-glycol solvation for $24 \mathrm{~h}$, and heating at $490{ }^{\circ} \mathrm{C}$ for two hours. Identification of clay minerals was made mainly according to the position of the $\left(\begin{array}{ll}0 & 0\end{array}\right)$ series of basal reflections on the three XRD diagrams. Semi-quantitative estimates of peak areas of the basal reflections for the main clay mineral groups of smectite (including mixed-layers) (15-17 $\AA$ ), illite (10 $)$ ), and kaolinite/chlorite (7 were carried out on the glycolated curve (Fig. 2) using the MacDiff software (Petschick, 2000) (cf. Pirlet et al., 2011). Mixed-layers mainly of smectite-illite (15-16 $\AA$ ) are included in "smectite". Relative proportions of kaolinite and chlorite were determined based on the ratio from the $3.57 / 3.54 \AA$ peak areas. The semiquantitative evaluation of each clay mineral has an accuracy of ca $4 \%$.

\subsection{Age model and time series analysis}

A new, integrated age model for the (Hole U1317E) Challenger Mound sequence is compiled in this study. Additional nannofossil and planktonic foraminifer age tiepoints are used to complement, evaluate and integrate all existing Hole U1317E chronostratigraphic data.
Within this new stratigraphic framework, the spectral features of selected time series are analysed and compared to the main orbital frequency bands. Only data sets with a sufficiently high temporal resolution are selected: planktonic $\delta^{18} \mathrm{O}$ (Sakai et al., 2009), matrix carbonate content (Titschack et al., 2009) and percentage siliciclastic grains deposited by high-energy bottom currents ('EMc'; Thierens et al., 2010) (average resolutions of 2.3, 4.4 and $0.7 \mathrm{ka}$ in M1, respectively). Using the Analyseries software by Paillard et al. (1996), the multi-taper method (6 tapers; Thomson, 1982) was applied to estimate amplitude spectra and statistical significance of spectral peaks. Multi-taper spectral analyses were run on unit M1 (1.723-2.580 Ma) data series only, as the condensed and fragmented nature of unit M2 makes it unfit for meaningful frequency analysis. Data points associated with ice-rafted detritus layers (cf. Thierens et al., 2010, 2012) were removed from the dataset to avoid overprinting of the primary (climate) signal. Subsequently, all data were linearly interpolated between the revised U1317E age at a regular, $1 \mathrm{ka}$ time interval. Potential frequency changes through time are assessed with a wavelet time-frequency decomposition (using the Morlet wavelet transform; e.g. Torrence and Compo, 1998).

\section{Results}

\subsection{Calcareous plankton assemblages}

\subsubsection{Calcareous nannofossils}

Calcareous nannofossils are abundant (i.e. average of $>50$ specimen per FOV) in most investigated samples (Supplementary Table ST1) and appear moderately to poorly preserved. Overall, U1317E nannofossil assemblages are dominated by the genera Coccolithus, Calcidiscus, Crenalithus and Helicosphaera. Gephyrocapsids first appear in common abundance in the record at $46.97 \mathrm{mbsf}$, after which they become one of the dominant genera (Table ST1, Fig. 2). Minor genera include Braarudosphaera, Discoaster, Pseudoemiliania, Reticulofenestra and Scyphosphaera. In addition, reworked, predominantly Cretaceous and MiddleMiocene nannofossil taxa are commonly observed (Table ST1).

Quantitative nannofossil assemblage analysis reveals the dominance of small G. caribbeanica and G. caribbeanica in the studied interval (0.68-51.77 mbsf) (Fig. 2). Both morphotypes are found in relatively low abundance in unit M1, below ca $30 \mathrm{mbsf}$ (average abundances of $16 \%$ and $4 \%$, respectively). Above ca $30 \mathrm{mbsf}$ (top M1, M2), both G. caribbeanica abundances increase significantly (averages of $32 \%$ and $27 \%$ ) and generally dominate the assemblages (Fig. 2). An inverse trend can be observed in the relative abundance of Crenalithus doronocoides, the third most abundant nannofossil species. Although a minor component of the floral assemblage (1\% on average), Helicosphaera carteri shifts mirror those of $C$. doronocoides (Fig. 2).

Several calcareous nannofossil biostratigraphic events are identified, as listed in Table S1 and Fig. 2 and discussed in the Supplementary Materials (for raw count data, see Supplementary Table ST1). Noteworthy is that Discoaster species (most notably $D$. brouweri, $D$. triradiatus and $D$. surculus) have rare occurrences in U1317E and mostly appear as single specimen in non-consecutive samples. The event between 146.31 and 145.46 mbsf consists of a distinct shift in the dominance between Coccolithus pelagicus and (small) Reticulofenestra, with Reticulofenestra being distinctly more abundant below 145.46 mbsf.

\subsubsection{Planktonic foraminifers}

In the majority of samples ( $>80 \%$ ), planktonic foraminifer tests are moderately to well preserved, allowing confident species identifications (Supplementary Table ST2). Dissolution features are rare 


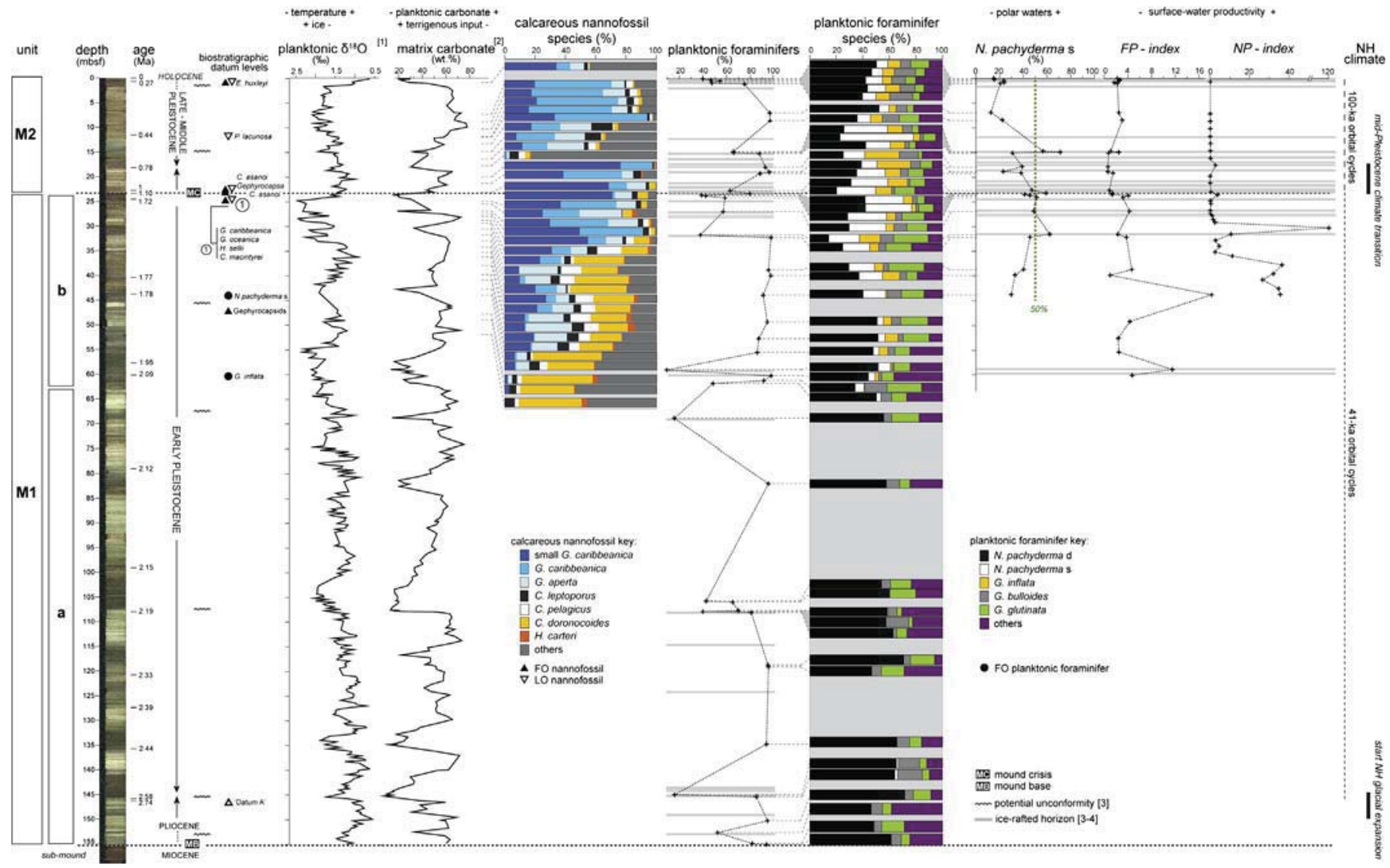

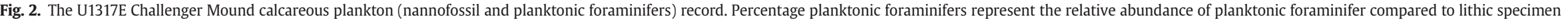

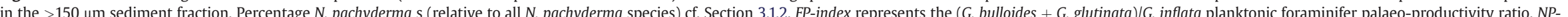

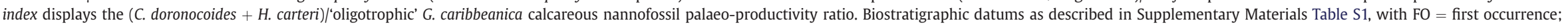

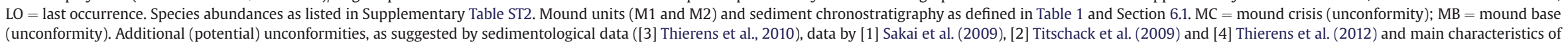
the Northern Hemisphere $(\mathrm{NH})$ climate system, for reference. All depths are in corrected metres below seafloor (mbsf). 


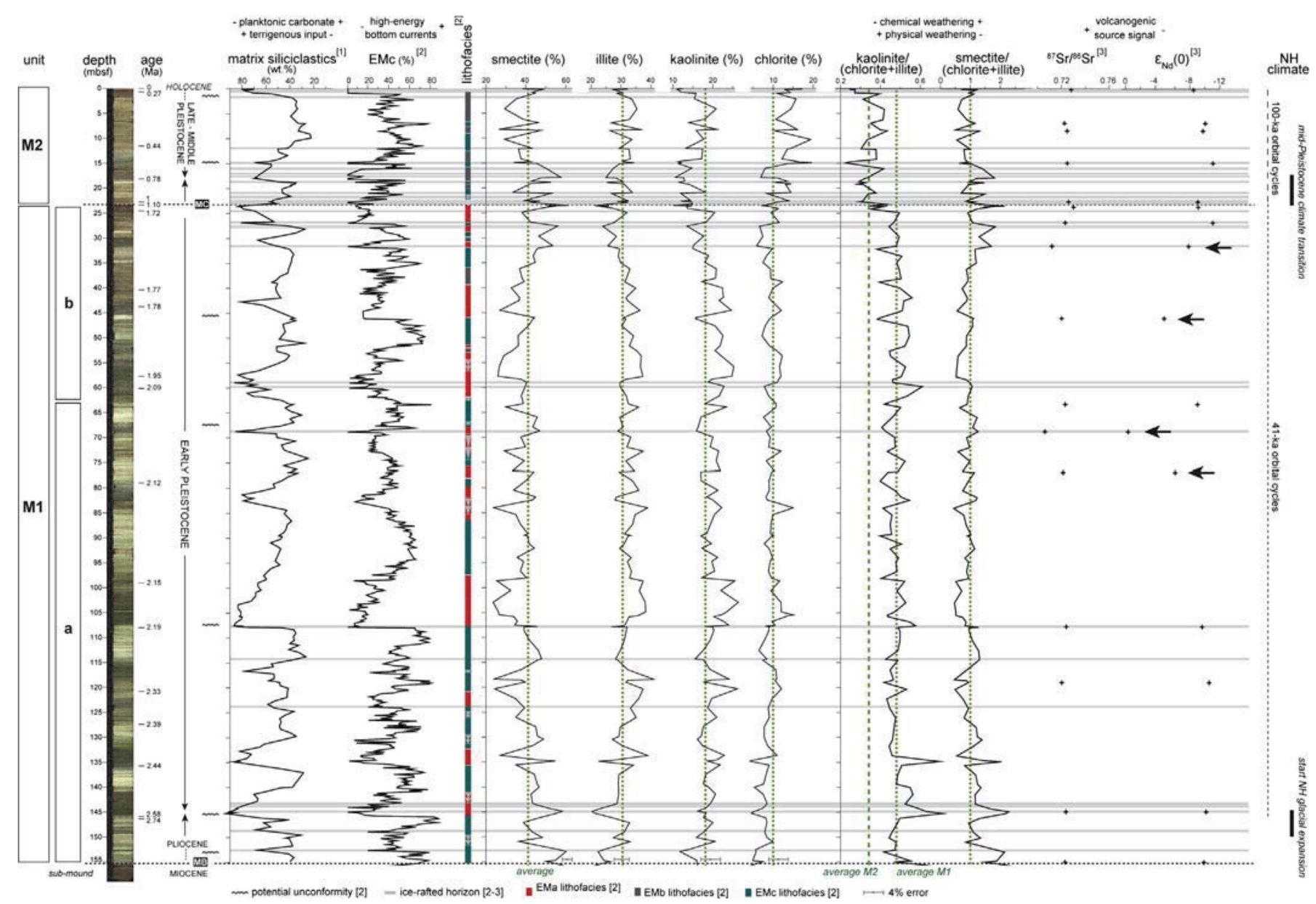

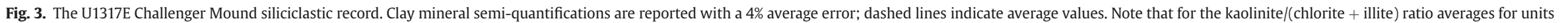

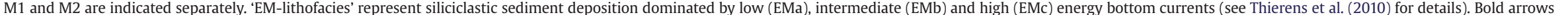

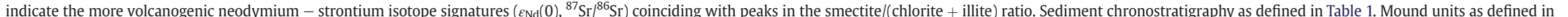
Fig. 4. Data from: [1] Titschack et al. (2009), [2] Thierens et al. (2010), [3]: Thierens et al. (2012) and this study. 
Table 1

U1317E integrated sediment stratigraphy. Synthesis of sediment-based age tiepoints for the U1317E mound sequence, as compiled and evaluated in this study. See Supplementary Materials for details.

\begin{tabular}{|c|c|c|c|c|}
\hline IODP sample code & $\begin{array}{l}\text { Depth } \\
\text { (mbsf) }\end{array}$ & $\begin{array}{l}\text { Age } \\
\text { (Ma) }\end{array}$ & Data source & Data reference \\
\hline 307-U1317E-1H-1-3 & 0 & 0.0001 & Radiocarbon date & Thierens et al., 2010 \\
\hline 307-U1317E-1H-1-68 & 0.68 & 0.265 & Nannofossil bioevent & This study \\
\hline 307-U1317E-2H-4-60 & 11.56 & 0.44 & Nannofossil bioevent & This study \\
\hline 307-U1317E-3H-2-50 & 18.15 & 0.78 & Palaeo-magnetic event & Foubert and Henriet, 2009 \\
\hline 307-U1317E-3H-5-77 & 22.78 & 1.00 & Nannofossil bioevent & This study \\
\hline 307-U1317E-3H-5-135 & 23.34 & 1.1 & Nannofossil bioevent & This study \\
\hline 307-U1317E-3H-6-107 & 24.53 & 1.72 & Nannofossil bioevent & This study \\
\hline 307-U1317E-5H-4-87 & 40.37 & 1.77 & Palaeo-magnetic event & Foubert and Henriet, 2009 \\
\hline 307-U1317E-5H-6-143 & 43.80 & 1.78 & Foraminifer bioevent & This study \\
\hline 307-U1317E-7H-3-60 & 57.73 & 1.95 & Palaeo-magnetic event & Foubert and Henriet, 2009 \\
\hline 307-U1317E-7H-5-3 & 60.12 & 2.09 & Foraminifer bioevent & This study \\
\hline 307-U1317E-9H-5-5 & 79.00 & 2.115 & Palaeo-magnetic event & Foubert and Henriet, 2009 \\
\hline 307-U1317E-11H-5-102 & 99.04 & 2.153 & Palaeo-magnetic event & Foubert and Henriet, 2009 \\
\hline 307-U1317E-12H-5-60 & 107.99 & 2.19 & Palaeo-magnetic event & Foubert and Henriet, 2009 \\
\hline 307-U1317E-14H-1-5 & 120.75 & 2.33 & Palaeo-magnetic event & Foubert and Henriet, 2009 \\
\hline 307-U1317E-14H-5-105 & 127.37 & 2.39 & Palaeo-magnetic event & Foubert and Henriet, 2009 \\
\hline 307-U1317E-15H-4-130 & 135.72 & 2.44 & Palaeo-magnetic event & Foubert and Henriet, 2009 \\
\hline 307-U1317E-16H-5-50 & 145.85 & 2.58 & $\begin{array}{l}\text { Revised palaeo-magnetic } \\
\text { event }\end{array}$ & This study \\
\hline 307-U1317E-16H-5-98 & 146.31 & 2.74 & Nannofossil bioevent & This study \\
\hline
\end{tabular}

to absent, although various degrees of secondary carbonate precipitation were frequently observed. In five samples heavy carbonate encrustation appears ubiquitously and prohibits a reliable faunal analysis (Table ST2). In all investigated samples, planktonic foraminifers comprise between 10 and 98\% of the coarse sediment fraction (i.e. planktonic foraminifers and lithic grains $>150 \mu \mathrm{m}$ ), parallelling the general trend displayed by the matrix carbonate content and planktonic foraminifer stable oxygen isotopes $\left(\delta^{18} \mathrm{O}\right)$ (Fig. 2). Planktonic assemblages predominantly consist of N. pachyderma dextral (14-71\%), N. pachyderma sinistral (0-55\%), Globigerinita glutinata (3-27\%), Globorotalia inflata (0-26\%) and Globigerina bulloides (0-18\%). Minor species ('others') include Globorotalia scitula, Globigerina quinqueloba, Orbulina universa, Globorotalia crassaformis and Neogloboquadrina dutertrei (Fig. 2, Table ST2).

Overall, mound unit M1 and M2 contain comparable planktonic foraminifer assemblages, with similar average abundances for all major species (Fig. 2). Apart from the evolutionary introduction of G. inflata and N. pachyderma s (see Fig. 2; Table S1), no major faunal shifts appear in the Challenger Mound sequence. Circa $87 \%$ of Challenger Mound foraminifer faunas are dominated by $N$. pachyderma d (overall average abundance: 45\%; Fig. 2, Table ST2). Similarly, all samples contain variable quantities of G. glutinata and G. bulloides (averages of $12 \%$ and $8 \%$, respectively). Within the precision of the counting procedure, the relative abundance and variability of minor planktonic species is mostly insignificant (i.e. $<5 \%$; Table ST2). However, a significantly higher abundance $(>10 \%)$ of both O. universa and G. crassaformis can be noted below ca 150 mbsf (base unit M1), while G. scitula frequently appears more abundant $(>5 \%)$ below ca 58 mbsf (unit M1a) (Table ST2). Between 43.80 mbsf and the 'mound crisis' unconformity (top unit M1b), $N$. pachyderma s becomes increasingly more abundant (Fig. 2). In this interval, $N$. pachyderma s - although generally subordinate to its dextrally-coiled genotype is the dominant $N$. pachyderma species ( $N$. pachyderma s $\%>50 \%$; Fig. 2) in three (carbonate-poor and/or siliciclastic-rich) samples... A ca $5 \%$ average reduction in G. glutinata and a similar increase in G. inflata abundance can be noted in unit M2 compared to unit M1.

\subsubsection{Palaeo-productivity indices}

To assess potential changes in palaeo-productivity, the abundance of high versus low productivity planktonic foraminifer and calcareous nannofossil species is evaluated. Planktonic foraminifer species such as G. bulloides and G. glutinata are typically associated with nutrient enriched surface waters, while others, such as G. inflata, prefer more oligotrophic water masses (Bé, 1977; Hemleben et al., 1989; Chapman, 2010). Similarly, like the genus Crenalithus (see Appendix), elevated abundances of $H$. carteri have been linked to more eutrophic surface-water conditions (Andruleit and Rogalla, 2002; Findlay and Giraudeau, 2002; Ziveri et al., 2004; Baumann et al., 2005). On the other hand, certain G. caribbeanica morphotypes identified in this study are classified by Bollmann (1997) as the oligotrophic and cold morphotypes of the genus Gephyrocapsa (see Appendix).

Since G. bulloides, G. glutinata and G. inflata occur in significant quantities throughout mound units M1b and M2 (Section 4.1.2), the ratio of $G$. bulloides + G. glutinata (high productivity species) versus G. inflata (low productivity species) is considered to represent a meaningful indicator of palaeo-productivity since ca $2 \mathrm{Ma}$ ('FP-index') (cf. Wienberg et al. (2010) for the late Quaternary NE Atlantic margin). As shown in Fig. 2, a significant shift in average FP-index can be noted between mound units M1b and M2 (values of 1.8 versus 4.9 , respectively). A drop in productivity, in particular due to lower G. glutinata and higher $G$. inflata relative abundances, is thereby revealed from the 'mound crisis' unconformity onwards (unit M2). The nannofossil palaeo-productivity indicator ('NP-index'), based on the H. carteri $+C$. doronocoides (high productivity) versus 'oligotrophic' G. caribbeanica (low productivity) ratio, corroborates the planktonic foraminifer signal. Around $30.37 \mathrm{mbsf}$ a clear switch to more oligotrophic and/or cooler surface-water conditions is observed (average values of 6 versus 20, above and below this point), which persist throughout unit M2.

\subsection{Clay mineralogy}

In all investigated Challenger Mound samples, smectite (24$62 \%)$, illite (20-41\%), kaolinite (10-26\%) and chlorite (4-20\%) minerals constitute the clay mineral assemblage (Fig. 3). In ca $81 \%$ of samples, smectite appears as the most dominant clay mineral phase, with overall average contributions of $41 \%$ (Fig. 3). Illite is the second most abundant mineral in the clay fraction (average: $31 \%$ ), while kaolinite and chlorite occur in distinctly lower quantities (averages of $18 \%$ and $10 \%$, respectively).

Downcore, significantly elevated smectite percentages occur in zones of increased ice-rafted material, especially around the unit 

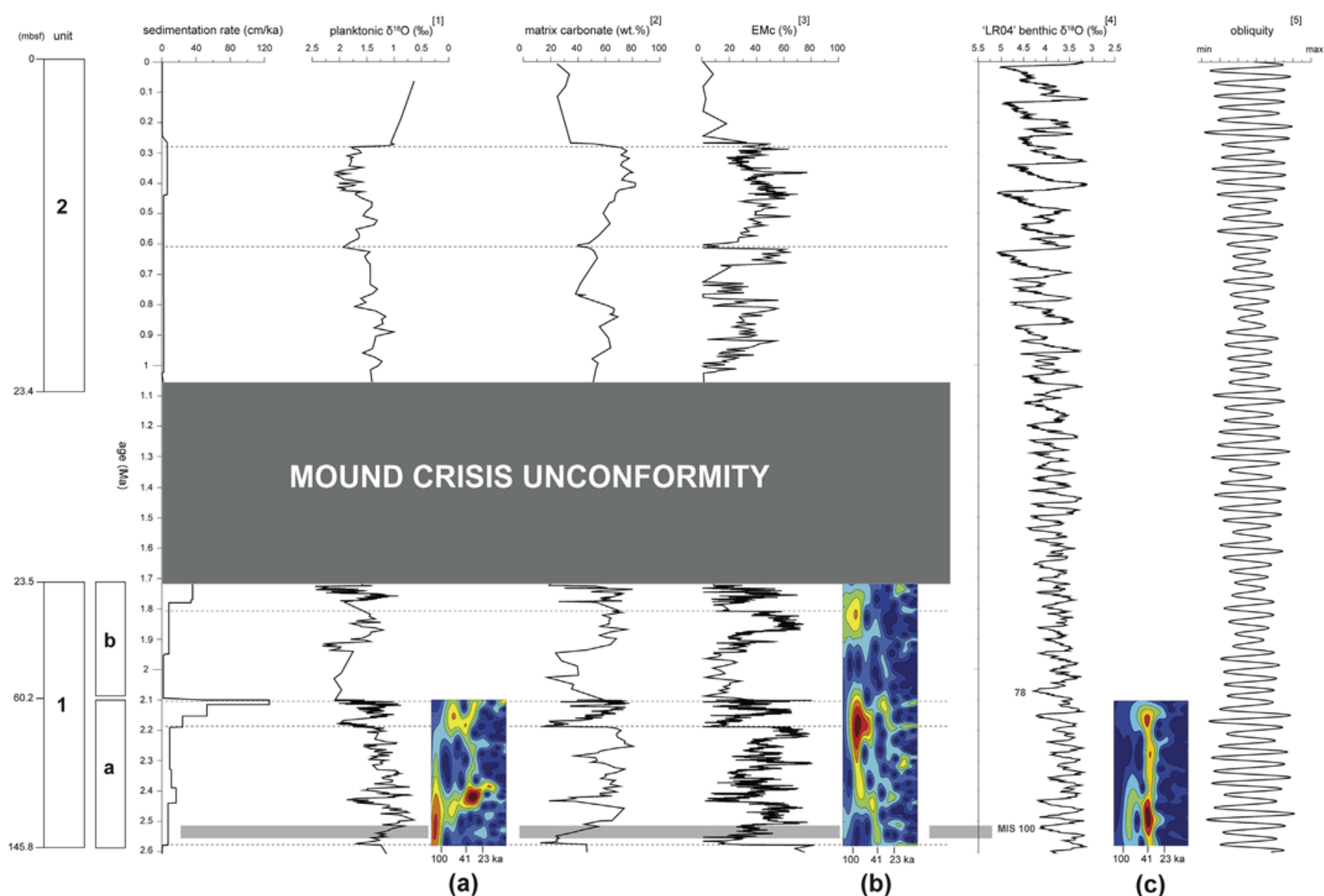

(c)

Fig. 4. Time-frequency features of cyclicities in selected U1317E Challenger Mound proxy records. Challenger Mound planktonic oxygen isotopes $\left(\delta^{18} \mathrm{O}\right)$, (weight) percentage carbonate (in the mound matrix) and percentage siliciclastic material deposited by high-energy bottom currents (EMc) versus 'LR04' global benthic $\delta^{18} \mathrm{O}$ variability between 0 and 2.6 Ma. Wavelet analysis of selected time slices in insets a-c (coloured contours represent spectral amplitudes, with blue: lowest amplitudes, red: highest amplitudes). U1317E sedimentation rates are assumed linear between the age tiepoints listed in Table 1. Dashed lines indicate sedimentologically-defined potential unconformities (Thierens et al., 2010). Note the reduced amplitude of the obliquity cycles in unit M1b and the occurrence of the first IRD pulse at marine isotope stage (MIS) 100. Data from: [1] Sakai et al. (2009), [2] Titschack et al. (2009), [3] Thierens et al. (2010), [4] Lisiecki and Raymo (2005) and [5] Berger and Loutre (1991). (For interpretation of the references to colour in this figure legend, the reader is referred to the web version of this article.)

M1 - unit M2 transition (16-32 mbsf) and directly above the mound base (unit M1 between ca 144 mbsf and 155.2 mbsf). Minor smectite fluctuations are frequent throughout the entire mound sequence. In unit M1, these changes show some similarity to the broad changes in matrix siliciclastics (Fig. 3). Generally, downcore variations in smectite abundance are inversely mirrored by the illite content and, to a lesser extent, by the relative proportions of kaolinite and chlorite. However, in contrast to smectite and illite, average kaolinite and chlorite percentages are significantly different between unit M1 and M2. On average, chlorite contributions increase with ca 5\% from M1 to M2 (9\% versus $13 \%$, respectively), while kaolinite abundances display an opposite evolution (19\% in M1 versus $14 \%$ in M2). Hence, the kaolinite/(chlorite + illite) ratio shows a clear shift at 'mound crisis' unconformity, from an average of 0.48 in M1 to one of 0.33 in M2. The smectite/ (chlorite + illite) ratio of both unit M1 and M2 fluctuates around 1. Elevated smectite/(chlorite + illite) ratios correlate with intervals of elevated smectite percentages, as described above.

\subsection{Time series analysis}

In mound unit M1 (between 1.72 and $2.58 \mathrm{Ma}$ ) all three independent proxies show comparable cyclicities with a dominant $90-$
120 ka periodicity, which falls within the eccentricity band of the insolation cycle (Figs. 4 and 5). Multiple weaker spectral peaks (albeit still highly significant) indicate the presence of additional periods that cluster between 40 and 50 ka (obliquity band) and around 22 and $18 \mathrm{ka}$ (precession band) (Fig. 5). Wavelet timefrequency analysis confirms the dominance of the ca $100 \mathrm{ka}$ period throughout the unit (Fig. 4). Only between 2.58 and $2.10 \mathrm{Ma}$ (unit M1a) ca 41 ka cycles appear more prominently (especially in the planktonic $\delta^{18} \mathrm{O}$ record), although rarely as the sole and/or main spectral component (insets a-b on Fig. 4). Spectral results proved to be independent of the resolution of the age model (different types and numbers of age tie-points tested; unpublished data).

\section{Integrated age model}

Overall, the biostratigraphic datums identified in this study confirm the stratigraphical data by Foubert and Henriet (2009) and Thierens et al. (2010) (Table 1; see Supplementary Materials for detailed discussion). The biostratigraphic markers reveal the presence of a significant, late Early Pleistocene (1.7-1.1 Ma) unconformity in the sediment sequence, between 24.53 and 23.34 mbsf; the 'mound crisis' unconformity (cf. Kano et al. (2007) for the $L$. pertusa cold-water coral stratigraphic record). The 
(A.)

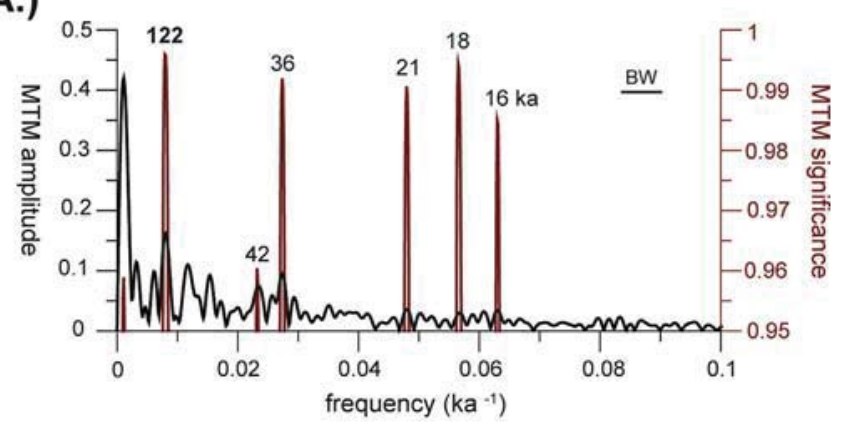

(B.)

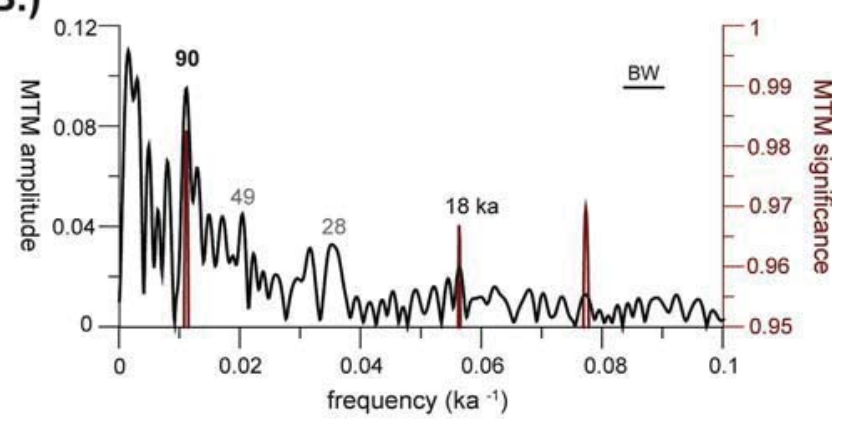

(C.)

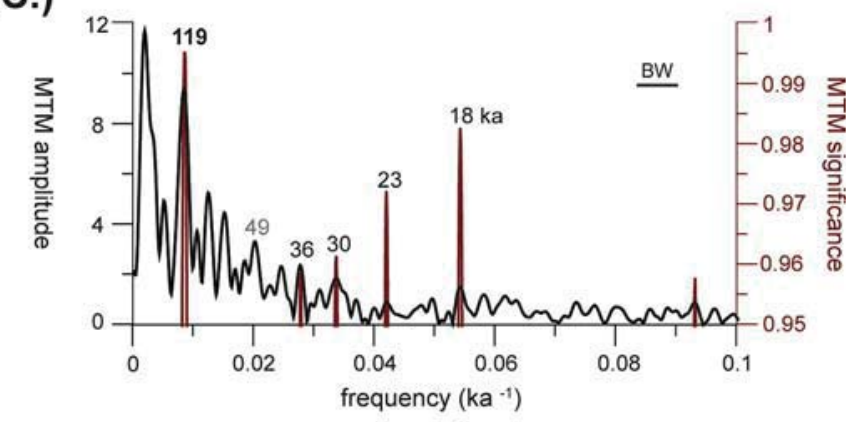

(D.)

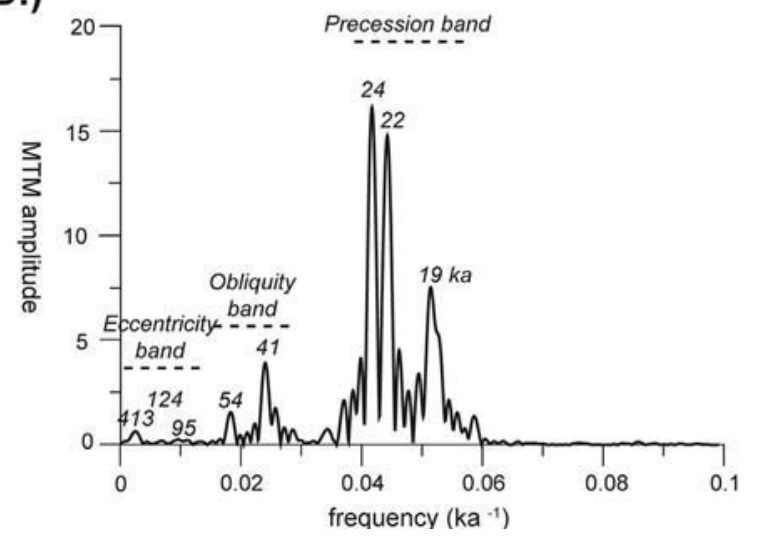

Fig. 5. Estimated spectral features of selected U1317E Challenger Mound proxy records. Multi-taper method (MTM) amplitude (in black) and significance (F-test; in red) of (A.) planktonic oxygen isotopes (Sakai et al., 2009), (B.) percentage EMc (Thierens et al., 2010), (C.) percentage matrix carbonate (Titschack et al., 2009) and (D.) July insolation at $51^{\circ} \mathrm{N}$ (Berger, 1978) over the interval 1.723-2.580 Ma (unit M1). Significant periods ( 1 /frequency) are indicated per plot. Periods in black have a minimal significance of 0.95; periods in grey one of minimal 0.90. MTM analysis has a bandwith (BW) of $0.007 \mathrm{ka}^{-1}$. (For interpretation of the references to colour in this figure legend, the reader is referred to the web version of this article.) detection of the 'Datum A' nannofossil event (Sato and Kameo, 1996; Sato et al., 2004) around 146 mbsf, moreover, refines the age of the basal mound units to the (Late) Pliocene $(>2.74 \mathrm{Ma})$. Integration of all the available U1317E sediment-based chronostratigraphic data (see also Supplementary Materials), as summarised in Table 1, provides a refined, multiproxy age estimate for the U1317E Challenger Mound sediments, consistent with the Kano et al. (2007) cold-water coral chronology (Fig. S1).

\section{The challenger mound palaeo-record}

Cyclic variations in Challenger Mound sediment proxies such as planktonic foraminifer stable oxygen isotopes $\left(\delta^{18} \mathrm{O}\right)$, luminosity, percentage planktonic carbonate in the mound-matrix sediments or magnetic susceptibility, have so far been attributed to environmental change on glacial-interglacial timescales (Ferdelman et al., 2006; Foubert and Henriet, 2009; Sakai et al., 2009; Titschack et al., 2009). The Challenger Mound record is thereby implied to reflect the astronomically-forced, and hence orbitally-paced fluctuations of the global Plio-Pleistocene climate system. Within the improved U1317E sediment chronostratigraphic framework, the nature of the Challenger Mound cyclicities can now be evaluated (Section 6.1). Subsequently, additional information from clay mineral, planktonic foraminifer and calcareous nannofossil assemblages will be added to further elucidate the Challenger Mound palaeo-environmental signal (Sections 6.2-6.3).

\subsection{Time series analysis: nature of the palaeo-record}

The presence of a 100 ka cyclicity in the Early Pleistocene has been observed in other marine proxy records (e.g. Clemens and Tiedemann, 1997; Kitamura and Kimoto, 2007; Nie et al., 2008; Lawrence et al., 2010; Medina-Elizalde and Lea, 2010). However, this signal is generally found to be weak compared to that of the obliquity component of the insolation cycle (41 ka), which typically governs pre-1.2 Ma Early Pleistocene glacial-interglacial variability (see inset c on Fig. 4) (e.g. Berger et al., 1998; Lisiecki and Raymo, 2005, 2007; Sosdian and Rosenthal, 2009; Lawrence et al., 2010). The overall dominance of a longer, ca $100 \mathrm{ka}$ period in the Challenger Mound (Figs. 4 and 5) could suggest a more complex (non-linear) response of the mixed carbonate/siliciclastic Challenger Mound environment to Early Pleistocene high-latitude (summer) insolation forcing.

Based on the chronostratigraphic and frequency analysis data, the Challenger Mound palaeo-record should be divided into four distinctly different units (Fig. 4):

(1) Mound unit M1a: containing the Early Pleistocene start-up phase of Challenger Mound development and its rapid $\left(31 \mathrm{~cm} \mathrm{ka}^{-1}\right.$ on average) growth until ca $2.1 \mathrm{Ma}$. In contrast to all other mound units, unit M1a periodicities show most affinity to the orbital pace of Pleistocene climate cycles (Fig. 4). $\delta^{18} \mathrm{O}$ amplitude differences are conform global benthic 'glacial-interglacial' $\delta^{18} \mathrm{O}$ variability for the same time interval (ca $1 \%$; Lisiecki and Raymo, 2005). High-resolution cycles of glacial (heavier $\delta^{18} \mathrm{O}$; relatively higher siliciclastic content) and interglacial (lighter $\delta^{18} \mathrm{O}$; relatively higher planktonic carbonate content) deposits seem therefore preserved in this part of the mound sequence (Fig. 4).

(2) Mound unit M1b: containing the slightly lower resolution (23 $\mathrm{cm} \mathrm{ka}^{-1}$ average sedimentation rate) top-most $37 \mathrm{~m}$ of the Early Pleistocene mound unit M1 (ca 2.1 to $1.7 \mathrm{Ma}$ ). In contrast to unit M1a, unit M1b spectral signatures only reveal low frequency (ca $100 \mathrm{ka}$ ) cyclicities in Challenger Mound proxy records (Fig. 4), although global climate variability remains at a higher, ca 41 ka pace (Fig. 4). In an environment that seems mostly susceptible to low frequency changes, the presence of 
lower-amplitude obliquity cycles between 2.1 and $1.7 \mathrm{Ma}$ (Fig. 4) could add to the specific spectral character of unit M1b. On the other hand, average unit $\mathrm{M} 1 \mathrm{~b} \delta^{18} \mathrm{O}$ values are slightly heavier than those of unit M1a, a trend also observed in global benthic $\delta^{18} \mathrm{O}$ records (Fig. 4).

(3) Mound crisis event: a significant hiatus in the depositional sequence, from ca 1.7 to $1.1 \mathrm{Ma}$, representing a period of erosion/non-deposition on the Challenger Mound.

(4) Mound unit M2: containing the late Early Pleistocene to Holocene (ca 1.1 Ma to recent) upper mound sequence. Sedimentation rates are very low ( $2 \mathrm{~cm} \mathrm{ka}^{-1}$ ) in this part of the sequence and $\delta^{18} \mathrm{O}$ amplitude differences are significantly lower than those of other NE Atlantic late Quaternary G. bulloides $\delta^{18} \mathrm{O}$ records (cf. Sakai et al., 2009). Selective preservation seems to significantly influence this part of the record (see next sections).

Overall, the global character of the Challenger Mound cyclicities seems challenged, except for the lower, unit M1a palaeo-record.

\subsection{Clay minerals: a record of British-Irish palaeo-environmental change?}

In marine sediments, clay mineral assemblages can reveal information on the palaeo-environmental conditions that governed continental weathering processes on adjacent landmasses ('climate') and/or on the petrology of the eroded source area ('provenance'), providing they are inherited ('detrital clays') and not formed in situ ('authigenic clays') (e.g. Chamley, 1989; Fagel, 2007; Hillier, 1995). Given the location of the study site (i.e. the NE Atlantic continental margin) and the absence of significant diagenetic alteration in the U1317E mound sequence (Foubert and Henriet, 2009; Frank et al., 2011), Challenger Mound clay mineral assemblages are considered to be mainly detrital. Moreover, the effect of transport-related differentiation processes (i.e. differential settling and/or resuspension of different clay minerals; Fagel, 2007) on the composition of these assemblages is expected to be limited, as (1) no systematic correlation can be noted between U1317E clay mineral variation and higher- versus lower-energy bottom-current deposits (see Fig. 3), (2) the U1317E smectite content is overall high (Fig. 3), despite smectite being most prone to reduced deposition under high-energy conditions (Hillier, 1995), and (3) the U1317E fine-grained and clay-rich siliciclastic fraction is mainly transported and deposited as particle-aggregates (Thierens et al., 2010). Hence, the Challenger Mound clay mineral associations can now be evaluated in terms of their climate (1) and provenance (2) signal:

(1) In continental areas, clay mineral formation is directly related to the intensity of physical versus chemical weathering processes, which in turn is governed by the prevailing climatic conditions in the sedimentary source area (Chamley, 1989). Smectite and kaolinite are mainly formed as the result of chemical weathering (hydrolysis) in warm and humid environments. Reduced water availability in colder and/or more arid climate zones, on the other hand, increases the impact of physical weathering processes and promotes the formation of illite and chlorite minerals (Chamley, 1989; Fagel, 2007). Therefore, if the Challenger Mound clay mineral assemblage would solely attest to changes in continental climate, increased smectite/(chlorite + illite) and kaolinite/(chlorite + illite) ratios should indicate the presence of warm and humid climate conditions (increased chemical versus physical weathering). Despite their significant variability downcore, U1317E clay mineral ratios do not reveal such a simple, unambiguous relationship. Both clay mineral ratios display strongly differing fluctuations, both in and out of phase, throughout the mound sequence (Fig. 3). Moreover, little correlation is found to the cyclic (climatic) variation displayed by other U1317E proxy records (Fig. 3). Instead, Challenger Mound clay mineral variability seems most clearly linked to (de-)glaciation related weathering changes. The significantly lower kaolinite/(chlorite + illite) ratios of the Middle-Late Pleistocene - Holocene (unit M2) compared to the Pliocene - Early Pleistocene (unit M1) concur with the increased physical weathering that accompanied the expansion and intensification of (continental) glaciations over the mid-Pleistocene climate transition (e.g. Clark et al., 2006; Bintanja and van de Wal, 2008; Sosdian and Rosenthal, 2009). The U1317E smectite/(chlorite + illite) ratio shows a marked increase in the Middle-Pleistocene interval (Fig. 3), which at first sight disagrees with the circum-Atlantic presence of extended glaciations. However, throughout the mound sequence, ice-rafted detritus (IRD) layers appear distinctly enriched in smectite (Fig. 3), suggesting a close link between an increased formation and/or input of smectite and the release of sediments by melting ice. Similar observations by Marioni et al. (2008), Vogt and Knies (2008) and Pirlet et al. (2011) have been attributed to the start-up of chemical weathering following glacial retreat. The onset of warmer climatic conditions and the release of meltwater during deglaciation thereby enhance hydrolysis and, hence, increase the input of smectite (and IRD) during deglaciation phases.

(2) In addition, Challenger Mound clay mineral assemblages result from the erosion of mineralogically different source areas. In this scenario, the increased smectite content in U1317E IRD deposits might indicate a shift in sediment provenance, with predominantly more smectite-rich source areas being subjected to glacial erosion. As isotopic provenance identifications by Thierens et al. (2012) constrained the main source area of U1317E (ice-rafted and current-influenced) deposits to the British-Irish Isles, changes in the presence, growth/decay and spatial extent of a British-Irish ice sheet might, therefore, govern the influx of smectite minerals in the Challenger Mound. Moreover, in selected samples, elevated smectite/(chlorite + illite) ratios coincide with neodymium-strontium isotope values indicative of a more volcanogenic (rather than a sedimentary or metamorphic) sediment source (Fig. 3). As volcanogenic smectite minerals are found abundantly in the Tertiary formations and soils of Ireland and Britain (Huggett and Knox, 2006) besides more distal NE Atlantic source areas such as Iceland or the Faeroe Islands (BoutRoumazeilles et al., 1999; Fagel et al., 2001), this correlation may suggest the episodic erosion of British-Irish volcanogenic terrains and, hence, illustrate subtle provenance changes within the British-Irish Isles. The less probable possibility is reserved that the smectite comes directly from the chemical weathering of volcanic ashes and glasses (Chamley, 1989).

Although climate and provenance signals are difficult to deconvolute, Challenger Mound (U1317E) clay mineral variability, and the abundance of smectite minerals in particular, appears most of all linked to the development of ice in the Northern Hemisphere and especially that on the islands of Ireland and Britain. Both the chemical (i.e. deglaciation hydrolysis) and physical (i.e. erosion of smectite-rich sources) environment for an increased input of smectite minerals during ice rafting events is thereby provided.

\subsection{Calcareous plankton: ice-rafting and surface-water productivity effects?}

\subsubsection{Plio-Pleistocene palaeo-climate}

The planktonic foraminifer assemblages observed in the Challenger Mound (U1317E) all consist predominantly of subarctic to 
transitional species (sensu Bé, 1977; Hemleben et al., 1989), while (sub-) tropical species, such as N. dutertrei, G. crassaformis or Globigerinoides ruber, are rare to absent (Fig. 2, Table ST2). Similar PlioPleistocene assemblages have been described in the North Atlantic by, e.g. Bé (1977), Channell et al. (2005) and Raymo et al. (1986) (IODP site U1308/DSDP site 609, mid-North Atlantic ridge), Flower (1999) (ODP site 981, Feni Drift), Hooper and Funnell (1986) (DSDP site 552, SW of Rockall Bank), Huvenne et al. (2009b) (IODP site U1317C, Challenger Mound) and Pujol and Duprat (1985) (DSDP site 548, Goban Spur).

While the relative abundance of planktonic foraminifers in the mound matrix follows the general cyclic trend observed in other U1317E variables, planktonic foraminifer faunal compositions, in contrast, reveal little comparable change (Fig. 2, Table ST2). Hence, although the Challenger Mound environment - including its calcareous plankton content - was subjected to periodical variability, surface water conditions remained within the environmental limits of the local planktonic foraminifer fauna. In unit M1, this limited environmental variability results most likely from the relatively moderate changes that characterised the Early Pleistocene. Average sea surface temperatures of $14-17{ }^{\circ} \mathrm{C}$, with glacialinterglacial differences of ca $4{ }^{\circ} \mathrm{C}$, have been reported from $\mathrm{N}$ Atlantic sites influenced by the North Atlantic Current during the Early Pleistocene (ODP 982, DSDP 607; Lawrence et al., 2010). Changes of a similar magnitude in the surface waters of the Shelf Edge Current (Fig. 1) would not be significant enough to impact the subarctic-transitional faunal assemblages at the Challenger Mound site. One exception is found in the lower ca $10 \mathrm{~m}$ of the mound sequence (late Pliocene). There, significantly increased abundances of the otherwise accessory, subtropical species G. crassaformis and O. universa (see Table ST2) indicate the presence of distinctly warmer surface-water conditions (cf. Huvenne et al. (2009b) for the basal units of site U1317C). The subsequent decrease in these warmer-water taxa over the Plio-Pleistocene transition (2.52.7 Ma), in conjunction with the first major pulse of British-Irish ice-rafting in the Challenger Mound environment (MIS 100; Figs. 2 and 4), concurs with the ca 2.75-2.55 Ma intensification of Northern Hemisphere ice-sheet expansion and its associated global cooling (cf. e.g. Maslin et al., 1998; Flesche Kleiven et al., 2002; Bartoli et al., 2005; Sosdian and Rosenthal, 2009; Lawrence et al., 2010; Naafs et al., 2010; Bailey et al., 2012). Although several other British-Irish ice-rafting events can be discerned in unit M1 (Section 2.2.1; Thierens et al., 2012), they did not leave a clear imprint in the planktonic foraminifer fauna, except for decreasing its overall (relative) abundance (Fig. 2). This results directly from the general lack of polar water taxa in Early Pleistocene (>1.8 Ma) NE Atlantic deposits (Raymo et al., 1986; Weaver and Clement, 1986). After $1.8 \mathrm{Ma}$ (top unit M1b, unit M2), IRD layers do appear relatively enriched in the polar species $N$. pachyderma s (Fig. 2) (cf. e.g. Heinrich, 1988; van Kreveld et al., 1996; Scourse et al., 2009). A significant surface water cooling due to the south/southeast-ward migration of the Polar/Arctic Front and the inflow of cold (polar) waters is implied in phase with British-Irish glaciations (cf. Scourse et al., 2009; Thierens et al., 2012). At the top of mound unit M1b, the gradual increase in the percentage $N$. pachyderma s, in conjunction with distinctly heavier $\delta^{18} \mathrm{O}$ values and multiple IRD horizons, indicates a period of increased, glaciation-related surface-water cooling leading up to the 'mound crisis event' (Fig. 2).

As for unit M1b, unit M2 planktonic foraminifer assemblages seem to respond most clearly to surface water perturbations induced by ice-rafting (Fig. 2). Overall, unit M2 faunal assemblages bear little evidence of the more extreme/extremely variable global climate system that is known to govern North-Atlantic palaeo-environments during the late Quaternary (e.g. Ruddiman et al., 1989; McManus et al., 1999; Lisiecki and Raymo, 2007). Remarkably, little compositional difference can be noted between mound units M1 and M2 (Fig. 2). Moreover, compared to the planktonic foraminifer fauna of Middle-Late Pleistocene off-mound drift deposits in Porcupine Seabight (Van Rooij et al., 2007; Huvenne et al., 2009b), unit M2 Challenger Mound assemblages contain significantly smaller proportions of the cold-water species N. pachyderma s (33\% versus 78\% for IODP Exp. 307 U1318 fauna (Huvenne et al., 2009b)). When interpreting unit M2 planktonic fauna solely in terms of palaeoclimate, these results seem to suggest the exclusive preservation of less extreme and more intermediate late Quaternary climatic conditions on-mound compared to those registered in off-mound NE Atlantic settings. However, similar to the unit M2 planktonic $\delta^{18} \mathrm{O}$ signal, the observed faunal compositions are probably significantly influenced by on-mound sediment preservation effects, besides palaeo-environmental variability (see Section 7.2).

\subsubsection{Surface-water palaeo-productivity}

Surface-water productivity changes can be caused by the episodic repositioning of water masses and/or hydrographic fronts (e.g. Schiebel et al., 2002; Stein et al., 2009; Naafs et al., 2010). The abundant occurrence of $G$. inflata (cf. unit M2) has been used to imply the presence of hydrographic fronts in the N Atlantic (e.g. IODP site U1308; Channell et al., 2005). Considering the timing of the Challenger Mound productivity decrease (NP- and FP-index decrease; Fig. 2) - coincident with the 'mound crisis' unconformity which has been linked to the mid-Pleistocene climate transition -, it might result from the oceanographic changes associated with this mid-Pleistocene transition. A similar scenario is well described at the Plio-Pleistocene transition (ca 2.75-2.55 Ma; e.g. Maslin et al., 1998; Sosdian and Rosenthal, 2009), where major water-mass migrations induced a significant and widespread productivity change in N Atlantic surface water masses (Sarnthein and Fenner, 1988; Naafs et al., 2010; Bolton et al., 2011). Besides this, distinctly expanded nearby ice development offers another plausible mechanism for productivity changes at the Challenger Mound site. The surface-water productivity drop noted here coincides with an increase in surface-water cooling and IRD input which accompany the switch to a more intensively glaciated Middle-Late Pleistocene environment (cf. previous sections; Fig. 2). Polar water mass migrations, sudden meltwater pulses, increased stratification and the (repeated) development of a proximal ice margin all have the potential to affect nutrient availability/primary productivity in the surface waters (cf. Henrich and Baumann, 1994; van Kreveld et al., 1996; Stein et al., 2009). Hence, surface-water productivity conditions in Porcupine Seabight might be tightly linked to the evolution of the adjacent British-Irish Ice Sheet.

Overall, the U1317E calcareous plankton assemblages suggest a direct link between Plio-Pleistocene surface-water perturbations at the Challenger Mound site and the glaciation history of the Northern Hemisphere. As the intensity and extent of (British-Irish) glaciations and associated oceanographic changes increased during the Middle-Late Pleistocene (unit M2) compared to the Early Pleistocene (unit M1), the stability of surface water conditions deteriorated accordingly.

\section{Implications}

\subsection{Palaeo-environmental influence on coral carbonate mound development}

As evident from the data presented in this study, the development of the Challenger coral carbonate mound can be directly related to and explained by the Plio-Pleistocene climatic evolution of the Northern Hemisphere. The Early Pleistocene environment, with its frequent though confined variability, seems optimal for 
rapid and continuous (i.e. glacial and interglacial) mound growth (unit M1), whereas the more extreme and variable setting of the late Quaternary significantly limited successful mound build-up (unit M2) at the site (Figs. 2 and 3). Moreover, the two major thresholds in Challenger Mound development - its initiation in the late Pliocene ( $>2.74 \mathrm{Ma}$; mound base) and its mid Pleistocene switch to decline ('mound crisis' unconformity) - coincide with the two major climate transitions of the Plio-Pleistocene: (1) the late Pliocene - early Pleistocene onset of Northern Hemisphere glacial expansion (ca 2.75-2.55 Ma; e.g. Maslin et al., 1998; Sosdian and Rosenthal, 2009) and (2) the mid-Pleistocene transition to the more extremely variable and more extensively glaciated late Quaternary (ca 1.2-0.65 Ma; e.g. Clark et al., 2006; Sosdian and Rosenthal, 2009) (cf. Kano et al., 2007; Titschack et al., 2009; Thierens et al., 2010).

Clearly, the extensive climatic and oceanographic changes at both transitions drastically (re-)defined the potential for coldwater coral growth and sediment accumulation at the Challenger Mound site. A whole suite of parameters, operating at various levels throughout the water column, could thereby have pushed conditions in-/outside the environmental range of continued (vertical) mound growth. Despite dynamic changes in the benthic environment (see Section 2.2.2; Fig. 3) (Huvenne et al., 2009b; Thierens et al., 2010) and implied intermediate water-mass variability (MOW, e.g. Sakai et al., 2009; Raddatz et al., 2011), our data suggest that glaciation-related surface-water perturbations played a key role. Throughout mound development, surface-water processes such as (polar) front migrations, meltwater pulses and increased sediment input during British-Irish ice-rafting events are all found to alter the Challenger Mound environment (Sections 6.2 and 6.3; Figs. 2 and 3). Most significant is, however, the coincidence of a distinct change in surface-water productivity with the timing of both mound initiation and decline (see Section 6.3.2). A fundamental link between Challenger Mound development and (glaciation-influenced) food influx is, therefore, implied. The availability of food is considered to be one of the main factors controlling contemporary cold-water coral growth (see Section 2.2.2). Besides 'primary' food availability (phytodetritus and/or zooplankton), sustained coral reef development along the Irish N Atlantic margin is mainly attributed to (secondary) food enrichment in the intermediate water-depth range of cold-water corals. The presence and position of nepheloid layers, water-mass boundaries and nutrientrich intermediate water masses is thereby assumed to define the optimal location/depth for cold-water coral growth through time (e.g. Duineveld et al., 2007; Kiriakoulakis et al., 2007; Mienis et al., 2007; Dullo et al., 2008; Sakai et al., 2009; White and Dorschel, 2010; Frank et al., 2011). This study, however, points towards a fundamental and long-term control by surface-water primary productivity/nutrient availability instead. The necessity for coldwater corals to growth within an 'optimal' (intermediate) water depth range, hence, appears related to additional processes (e.g. particle transport and nutrient redistribution), with an undeniable albeit secondary importance.

In a setting that is heavily influenced by proximal ice development, such as the Irish continental margin (see Section 6), the impact of surface-water perturbations might be more pronounced than elsewhere. However, also in lower-latitude East Atlantic, as well as West Atlantic areas surface-water processes (and productivity) are found to drive cold-water coral and mound growth (e.g. Wienberg et al., 2010; Eisele et al., 2011; Mienis et al., 2012), stressing the larger-scale importance of this mechanism. Nevertheless, the location of the Challenger Mound on the Irish Atlantic margin had an undeniable impact on its evolution. The dynamics and extent of Northern Hemisphere Plio-Pleistocene ice development and especially that on the local, British-Irish Isles, clearly defined the fate of Challenger and potentially other Porcupine Seabight coral carbonate mounds.

\subsection{Coral carbonate mounds as palaeo-archives}

In the North Atlantic, Quaternary deep-sea proxy records generally reveal fluctuations on orbital timescales, illustrating the inherent variability of the global climate system (e.g. Zimmerman et al., 1984; Raymo et al., 1986; Shackleton et al., 1995; Lisiecki and Raymo, 2005, 2007). As evident from Section 6, the PlioPleistocene continental margin signal recorded in the Challenger Mound matrix sediments, in comparison, reveals a more complex archive.

Overall, the Challenger Mound palaeo-record shows a great affinity to the climate variability of the Plio-Pleistocene Northern Hemisphere (cf. Sections 6, 7.1). However, its frequency of change is not entirely in phase with that of global climate (cf. Section 6.1). Most likely, this offset results from the unique continental margin setting in which the Challenger Mound record is formed and the strong impact of local factors therein. Most clearly, the preservation of any matrix record at the Challenger Mound site is tightly linked to the environmental feasibility of on-mound sediment accumulation and, hence, cold-water coral reef development. The presence of a dense cold-water coral framework is found to promote sediment accumulation (i.e. deposition and preservation) on-mound, even in a highly dynamic depositional environment (e.g. Mienis et al., 2009a). Moreover, López Correa et al. (2012) show that during periods of fast coral reef growth, matrix sediment accumulates with a minimal temporal offset (ca 150-250 yr for Holocene Norwegian coral reefs) in between the coral framework. Hence, not surprisingly, the most 'optimal' palaeo-record (i.e. high-resolution and with most affinity to global climate variability) in the Challenger Mound is associated with the most optimal period for coral development, and therefore, for fast mound sediment accumulation at the site: the Early Pleistocene (unit M1). Conversely, struggling cold-water coral growth in the Middle-Late Pleistocene to Holocene (unit M2) inevitably resulted in a reduced and selective preservation of sediment on-mound (cf. Thierens et al., 2010), which in turn led to the creation of a low-resolution, condensed and fragmented record for this time interval. The unusual, limited environmental variability and intermediate nature of late Quaternary mound sequences (see Section 6; Dorschel et al., 2005) can be attributed to on-mound preservation effects. Climatically-induced changes in cold-water coral density (cf. Section 7.1) to have contributed to the development of two clearly different PlioPleistocene palaeo-records, whose resolution contrasts strongly with other NE Atlantic continental margin sequences (Fig. 4) (versus e.g. Stoker et al., 1994; Knutz et al., 2007). Besides cold-water coral growth, the proximity of a (calving) British-Irish ice sheet presents another mechanism for adding a more local signal to the Challenger Mound record. The oceanographic, sedimentological and climatic changes associated with the Plio-Pleistocene evolution of BritishIrish ice-sheet development are most strongly reflected in Challenger Mound proxy records (Figs. 2 and 3; Sections 6.2-6.3). The preservation of this 'local' signal, fortuitously, has meant that an exceptional record of early Pleistocene mid-latitudinal circumAtlantic glaciation is captured in the Challenger Mound sequence (Thierens et al., 2012). The wider relevance of the Challenger Mound record is, therefore, evident.

Albeit influenced by both global and local factors, the potential to capture unique records from complex continental margin environments constitutes the regional value of coral carbonate mound archives. In this way, coral carbonate mound sequences might provide a unique insight into less explored environments and/or time intervals. 


\section{Conclusions}

- The biostratigraphic refinement of the Challenger Mound (Hole U1317E) sediment chronostratigraphy overall confirms the previously established Late Pliocene/Early Pleistocene to Late Pleistocene/Holocene age of the mound sequence. However, the onset of Challenger Mound (sediment) accumulation is refined to the late Pliocene ( $>2.74 \mathrm{Ma})$, within the Plio-Pleistocene transition towards a more glaciated Northern Hemisphere.

- Time series analysis of independent climate proxy records (planktonic foraminifer oxygen isotopes, matrix carbonate content) reveals the predominant ca $100 \mathrm{ka}$ periodicity of Challenger Mound cyclicities throughout the Pleistocene. Only between ca 2.6 and $2.1 \mathrm{Ma}$, in the fast accumulated lower mound (M1a), a typical Early Pleistocene period of 41 ka suggests a high-resolution record broadly in phase with the global climate system. The Middle-Late Pleistocene to Holocene upper mound (M2), on the other hand, seems predominantly affected by sediment preservation effects.

- Additional palaeo-environmental proxy data (clay mineral, planktonic foraminifer and calcareous nannofossil assemblages) demonstrate the significant impact of Northern Hemisphere ice-sheet dynamics and British-Irish ice development, in particular, on the Challenger Mound environment. The waxing and waning of an ice mass on the British-Irish Isles since the earliest Pleistocene clearly affects the input of clay minerals (and especially smectites) at the Challenger Mound site. Moreover, planktonic foraminifer and calcareous nannofossil assemblages suggest a direct link between PlioPleistocene surface-water perturbations at the site and the intensity and extent of Northern Hemisphere ice-sheet development. Glaciation-related surface-water/frontal migrations, surface-water productivity changes and meltwater pulses are all found to alter the stability of the surface water conditions.

- The development of the Challenger coral carbonate mound can be directly related to the Plio-Pleistocene evolution of the Northern Hemisphere climate system and its glacial component, specifically. Glaciation-induced shifts in surface-water primary productivity are implied as a fundamental control on cold-water coral growth and, hence long-term coral carbonate mound development. The two major oceanographic and climatic transitions of the Plio-Pleistocene - the Late Pliocene/ Early Pleistocene intensification of continental ice-sheet development and the mid-Pleistocene transition to the more extremely variable and more extensively glaciated late Quaternary - thereby mark two significant thresholds in Challenger Mound development: its Late Pliocene origin and its Middle-Late Pleistocene to recent decline.

- The Challenger Mound palaeo-record shows an overall great affinity to the general climate variability of the Northern Hemisphere, despite not being completely in phase with it. Local influences, such as proximal (British-Irish) ice-sheet dynamics and on-mound changes in cold-water coral density, however play an equally crucial role. The interaction of local and global factors could potentially explain the unique nature of the Challenger Mound palaeo-record and its offsets with the periodicities of global climate variability. Most importantly, it enabled the preservation of a regionally unique, highresolution palaeo-record of Late Pliocene/Early Pleistocene (ca 2.6 to $2.1 \mathrm{Ma}$ ) environmental change, broadly in phase with the $41 \mathrm{ka}$-paced global climate system in the most successful phase of Challenger Mound build-up. Overall, the potential to capture unique records from complex (continental margin) environments clearly highlights the wider relevance of coral carbonate mound archives.

\section{Acknowledgements}

The authors thank the IODP Exp. 307 shipboard crew and scientists for providing this study's scientific framework and core material. M. De Batist and S. Louwye are kindly thanked for facilitating part of the foraminifer analyses, P. Weaver for help with foraminifer taxonomy and T. Williams and E. Jarvis for constructive comments on earlier versions of this manuscript. We are also very grateful to F. Mienis and M. López Correa for their in-depth reviews. This research was funded by the Marine Institute of Ireland, with the support of the Geological Survey of Ireland and the ESF EuroCORES EuroMarc CARBONATE programme. E. Browning was funded by a JOI-USSP grant for IODP Exp. 307 post-cruise research. V. Huvenne received support from the HERMIONE project (grant agreement number 226354). A. Foubert was funded through a FWO grant (Research Foundation Flanders).

\section{Appendix A}

\section{C. doronocoides palaeo-ecology}

The (palaeo-)ecologic affinity of $C$. doronocoides is largely unknown both due to a lack of studies on this taxon as well as ambiguous taxonomy. In this study, the ecologic preferences of C. doronocoides are based on the amendment by de Kaenel et al. (1999) for the genus Crenalithus and the ecological descriptions by Marino et al. (2008) for Reticulofenestra spp. in the North Atlantic (DSDP 607) and Eastern Mediterranean (ODP 967). As descriptions of Reticulofenestra spp. made by Marino et al. (2008) fit closely with the diagnostic characteristics for the genus Crenalithus provided in the amendment by de Kaenel et al. (1999), we suggest that the Marino et al. (2008) Reticulofenestra asanoi and Reticulofenestra spp. taxa are likely members of the genera Crenalithus (sensu de Kaenel et al., 1999). Since the species described by Marino et al. (2008) display an ecologic preference for more eutrophic surface-water conditions, we suggest that the genus Crenalithus, in fact, may have an eutrophic affinity.

\section{G. caribbeanica palaeo-ecology}

According to the classification system of Bollmann (1997), Gephyrocapsa specimen with a mean bridge angle between $27^{\circ}$ and $56^{\circ}$ and a mean length larger than $3.1 \mu \mathrm{m}$ represent the oligotrophic ('GO') Gephyrocapsa morphotype. Specimen with a mean bridge angle less than $27^{\circ}$ and a mean length larger than $2.4 \mu \mathrm{m}$ embody the cold ('GC') morphotype of the genus. Hence, the 'large' G. caribbeanica morphotype identified in this study (i.e. 3-4 $\mu \mathrm{m}$ mean length and bridge angle smaller than $40^{\circ}$ ) can be associated with oligotropic as well as cooler surface-water conditions.

\section{Appendix B. Supplementary data}

Supplementary data related to this article can be found at http:// dx.doi.org/10.1016/j.quascirev.2013.05.006.

\section{References}

Andruleit, H.A., Rogalla, U., 2002. Coccolithophores in surface sediments of the Arabian Sea in relation to environmental gradients in surface waters. Marine Geology 186, 505-526.

Adkins, J.F., Cheng, H., Boyle, E.A., Druffel, E.R.M., Edwards, R.L., 1998. Deep-sea coral evidence for rapid change in ventilation of the deep North Atlantic 15,400 years ago. Science $280,725-728$.

Bailey, I., Foster, G.L., Wilson, P.A., Jovane, L., Storey, C.D., Trueman, C.N., Becker, J., 2012. Flux and provenance of ice-rafted debris in the earliest Pleistocene subpolar North Atlantic Ocean comparable to the Last Glacial maximum. Earth and Planetary Science Letters 341-344, 222-233. 
Bartoli, G., Sarnthein, M., Weinelt, M., Erlenkeuser, H., Garbe-Schönberg, D., Lea, D.W., 2005. Final closure of Panama and the onset of northern hemisphere glaciation. Earth and Planetary Science Letters 237, 33-44.

Baumann, K.-H., Andruleit, H.A., Boeckel, B., Geisen, G., Kinkel, M., 2005. The significant of extant coccolithophores as indicators of ocean water masses, surface water temperature, and paleoproductivity: a review. Paläontologische Zeitschrift 79, 93-112.

Baumann, K.-H., Freitag, T., 2004. Pleistocene fluctuations in the northern Benguela Current system as revealed by coccolith assemblages. Marine Micropaleontology 52, 195-215.

Bé, A.W.H., 1977. An ecological, zoographic and taxonomic review of recent planktonic foraminifera. In: Ramsay, A.T.S. (Ed.), Oceanic Micropaleontology. Academic Press, London, pp. 1-100.

Berger, A., Loutre, M.-F., 1991. Insolation values for the climate of the last 10 million years. Quaternary Science Reviews 10, 297-317.

Berger, A., Loutre, M.-F., Mélice, J.L., 1998. Instability of the astronomical periods over the last and next millions of years. Paleoclimate Data and Modelling 2 , 239-280.

Berger, A.L., 1978. Long-term variations of daily insolation and Quaternary climatic changes. Journal of Atmospheric Sciences 35, 2363-2367.

Bintanja, R., van de Wal, R.S.W., 2008. North American ice-sheet dynamics and the onset of 100,000-year glacial cycles. Nature 454, 869-872.

Bollmann, J., 1997. Morphology and biogeography of Gephyrocapsa coccoliths in Holocene sediments. Marine Micropaleontology 29, 319-350.

Bolton, C.T., Lawrence, K.T., Gibbs, S.J., Wilson, P.A., Herbert, T.D., 2011. Biotic and geochemical evidence for a global latitudinal shift in ocean biogeochemistry and export productivity during the late Pliocene. Earth and Planetary Science Letters 308, 200-210.

Bout-Roumazeilles, V., Cortijo, E., Labeyrie, L., Debrabant, P., 1999. Clay mineral evidence of nepheloid layer contributions to the Heinrich layers in the northwest Atlantic. Palaeogeography, Palaeoclimatology, Palaeoecology 146, $211-228$.

Chamley, H., 1989. Clay Sedimentology. Springer-Verlag, New York Berlin Heidelberg, p. 623.

Chang, Y.M., 1967. Accuracy of fossil percentage estimation. Journal of Paleontology 41, 500-502.

Channell, J.E.T. Kanamatsu, T., Sato, T., Stein, R., Alvares Zarikian, C.A., Malone, M.J. The Expedition 303/306 Scientists, 2005. Proceedings of the Integrated Ocean Drilling Program, vol. 303/306. Integrated Ocean Drilling Program Management International, Inc., College Station TX http://dx.doi.org/10.2204/ iodp.proc.303306.108.2006

Chapman, M.R., 2010. Seasonal production pattern of planktonic foraminifera in the NE Atlantic Ocean: implications for paleotemperature and hydrographic reconstructions. Paleoceanography 25, PA1101. http://dx.doi.org/10.1029/ 2008PA001708.

Clark, P.U., Archer, D., Pollard, D., Blum, J.D., Rial, J.A., Brovkin, V., Mix, A.C., Pisias, N.G., Roy, M., 2006. The middle Pleistocene transition: characteristics, mechanisms, and implications for long-term changes in atmospheric $\mathrm{pCO}_{2}$. Quaternary Science Reviews 25, 3150-3184.

Clemens, S.C., Tiedemann, R., 1997. Eccentricity forcing of Pliocene - early Pleistocene climate revealed in a marine oxygen-isotope record. Nature 385, 802804

Colin, C., Frank, N., Copard, K., Douville, E., 2010. Neodymium isotopic composition of deep-sea corals from the NE Atlantic: implications for past hydrological changes during the Holocene. Quaternary Science Reviews 29.

Copard, K. Colin, C. Douville, E. Freiwald, A., Gudmundsson, G, De Mol, B. Frank, N., 2010. Nd isotopes in deep-sea corals in the north-eastern Atlantic. Quaternary Science Reviews 29, 2499-2508.

Copard, K., Colin, C., Henderson, G.M., Scholten, J., Douville, E., Sicre, M.A., Frank, N., 2012. Late Holocene intermediate water variability in the northeastern Atlantic as recorded by deep-sea corals. Earth and Planetary Science Letters 313-314, $34-44$.

Davies, A.J., Duineveld, G., Lavaleye, M.S.S., Bergman, M.J.N., van Haren, H., Roberts, J.M., 2009. Downwelling and deep-water bottom currents as food supply mechanisms to the cold-water coral Lophelia pertusa (Scleractinia) at the Mingulay Reef complex. Limnology and Oceanography 54, 620-629.

de Haas, H., Mienis, F., Frank, N., Richter, T., Steinacher, R., de Stigter, H.C., van der Land, C., van Weering, T.C.E., 2009. Morphology and sedimentology of (clustered) cold-water coral mounds at the south Rockall Trough margins, NE Atlantic Ocean. Facies 55, 1-26.

de Kaenel, E., Siesser, W.G., Murat, A., 1999. Pleistocene calcareous nannofossil biostratigraphy and the Western Sapropels, sites 974 to 977 and 979. In: Zahn, R., Comas, M.C., Klaus, A. (Eds.). Proceedings of the Ocean Drilling Program, Scientific Results, vol. 161. Ocean Drilling Program, College Station, TX pp. 159-183.

De Mol, B., Van Rensbergen, P., Pillen, S., Van Herreweghe, K., Van Rooij, D. Huvenne, V.A.I., McDonnell, A., Ivanov, M., Swennen, R., Henriet, J.P., 2002. Large deep-water coral banks in the Porcupine Basin, southwest of Ireland. Marine Geology 188, 193-231.

Dorschel, B., Hebbeln, D., Foubert, A., White, M., Wheeler, A.J., 2007. Hydrodynamics and cold-water coral facies distribution related to recent sedimentary processes at Galway Mound west of Ireland. Marine Geology 244, 184-195.

Dorschel, B., Hebbeln, D., Rüggeberg, A., Dullo, W.-C., Freiwald, A., 2005. Growth and erosion of a cold-water coral covered carbonate mound in the Northeast
Atlantic during the Late Pleistocene and Holocene. Earth and Planetary Science Letters 233, 33-44.

Dorschel, B., Wheeler, A.J., Monteys, X., Verbruggen, K., 2010. Atlas of the Deepwater Seabed: Ireland. Springer, Dordrecht Heidelberg London New York, p. 164.

Duineveld, G., Lavaleye, M.S.S., Bergman, M.J.N., de Stigter, H.C., Mienis, F., 2007. Trophic structure of a cold-water coral mound community (Rockall Bank, NE Atlantic) in relation to the near-bottom particle supply and current regime. Bulletin of Marine Science 81, 449-467.

Dullo, W.-C., Flögel, S., Rüggeberg, A., 2008. Cold-water coral growth in relation to the hydrography of the Celtic and Nordic European continental margin. Marine Ecology - Progress Series 371, 165-176.

Eisele, M., Frank, N., Wienberg, C., Hebbeln, D., López Correa, M., Douville, E., Freiwald, A., 2011. Productivity controlled cold-water coral growth periods during the last glacial off Mauritania. Marine Geology 280, 143-149.

Eisele, M., Hebbeln, D., Wienberg, C., 2008. Growth history of a cold-water coral covered carbonate mound - Galway Mound, Porcupine Seabight, NE-Atlantic. Marine Geology 253, 160-169.

Fagel, N., 2007. Clay minerals, deep circulation and climate. In: Hillaire-Marcel, C., De Vernal, A. (Eds.), Proxies in Late Cenozoic Paleoceanography. Developments in Marine Geology. Elsevier, Amsterdam, pp. 139-184.

Fagel, N., Robert, C., Preda, M., Thorez, J., 2001. Smectite composition as a tracer of deep circulation: the case of the Northern North Atlantic. Marine Geology 172, 309-330.

Ferdelman, T.G., Kano, A., Williams, T., Henriet, J.P., IODP Exp. 307 Scientists, 2006. Proceedings of the IODP Expedition 307. Modern Carbonate Mounds: Porcupine Drilling. IODP Management International, Washington DC. http://dx.doi.org/ 10.2204/iodp.proc.307.2006.

Findlay, C.S., Giraudeau, J., 2002. Movement of oceanic fronts South Australia during the last $10 \mathrm{ka}$ interpretation of calcareous nannoplankton in surface sediments from the Southern Ocean. Marine Micropaleontology 46, 431-444.

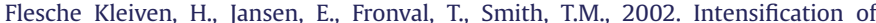
northern hemisphere glaciations in the circum Atlantic region (3.5-2.4 Ma) ice-rafted detritus evidence. Palaeogeography, Palaeoclimatology, Palaeoecology $184,213-223$.

Flores, J.A., Marino, M., 2002. Pleistocene calcareous nannofossil stratigraphy for ODP Leg 177 (Atlantic sector of the Southern Ocean). Marine Micropaleontology $45,191-224$.

Flower, B.P., 1999. Data report: planktonic foraminifers from the subpolar North Atlantic and Nordic Seas: sites 980-987 and 907. In: Raymo, M.E., Jansen, E., Blum, P., Herbert, T.D. (Eds.). Proceedings of the Ocean Drilling Program, Scientific Results, vol. 162. Ocean Drilling Program, College Station, TX, pp. 19-34.

Foubert, A., Henriet, J.P., 2009. Nature and Significance of the Recent Carbonate Mound Record: the Mound Challenger Code. Springer-Verlag, Heidelberg, p. 350 .

Foubert, A., Van Rooij, D., Blamart, D., Henriet, J.P., 2007. X-ray imagery and physical core logging as a proxy of the content of sediment cores in cold-water coral mound provinces: a case study from Porcupine Seabight, SW of Ireland. International Journal of Earth Sciences 96, 141-158.

Frank, N., Freiwald, A. López Correa, M., Wienberg C., Eisele, M., Hebbeln, D., Van Rooij, D., Henriet, J.P., Colin, C., van Weering, T.C.E., de Haas, H., BuhlMortensen, P., Roberts, J.M., De Mol, B., Douville, E., Blamart, D., Hatte, C., 2011. Northeastern Atlantic cold-water coral reefs and climate. Geology 39, 743-746.

Frank, N., Paterne, M., Ayliffe, L., van Weering, T.C.E., Henriet, J.P., Blamart, D., 2004 Eastern North Atlantic deep-sea corals: tracing upper intermediate water $\Delta^{14} \mathrm{C}$ during the Holocene. Earth and Planetary Science Letters 219, 297-309.

Frank, T.D., Titschack, J., Thierens, M., 2011. Aragonite loss in a modern cold-water coral mound: mechanisms and implications. Sedimentology 58, 670-690.

Freiwald, A., Fossa, J.H., Grehan, A., Koslow, T., Roberts, J.M., 2004. Cold-water Coral Reefs. In: Biodiversity Series. UNEP-WCMC, Cambridge, p. 84.

Hansen, B., Østerhus, S., 2000. North Atlantic-Nordic seas exchanges. Progress in Oceanography $45,109-208$

Heinrich, H., 1988. Origin and consequences of cyclic ice rafting in the northeast Atlantic ocean during the past 130,000 years. Quaternary Research 29, 142-152.

Hemleben, C., Spindler, M., Anderson, O.R., 1989. Modern Planktonic Foraminifera. Springer-Verlag, New York, p. 363

Henrich, R., Baumann, K.-H., 1994. Evolution of the Norwegian Current and the Scandinavian Ice Sheets during the past 2.6 m.y.: evidence from ODP Leg 104 biogenic carbonate and terrigenous records. Palaeogeography, Palaeoclimatology, Palaeoecology 108, 75-94

Hillier, S., 1995. Erosion, sedimentation and sedimentary origin of clays. In: Velde, B. (Ed.), Origin and Mineralogy of Clays. Springer-Verlag, Berlin, pp. 162-219.

Hooper, P.W.P., Funnell, B.M., 1986. Late Pliocene to recent planktonic foraminifera from the North Atlantic (DSDP site 552A): quantitative palaeotemperature analysis. In: Summerhayes, C.P., Shackleton, N.J. (Eds.), North Atlantic Palaeoceanography. Geological Society Special Publications, pp. 181-190.

Huggett, J.M., Knox, R.W.O.B., 2006. Clay mineralogy of the tertiary onshore and offshore strata of the British Isles. Clay Minerals 41, 5-46.

Huvenne, V.A.I., Bailey, W.R., Shannon, P.M., Naeth, J., di Primio, R., Henriet, J.P., Horsfield, B., de Haas, H., Wheeler, A.J., Olu- Le Roy, K., 2007. The Magellan mound province in the Porcupine Basin. International Journal of Earth Sciences 96, 85-101. 
Huvenne, V.A.I., Masson, D.D., Wheeler, A.J., 2009a. Sediment dynamics of a sandy contourite: the sedimentary context of the Darwin cold-water coral mounds, Northern Rockall Trough. International Journal of Earth Sciences 98, 865-884.

Huvenne, V.A.I., Tyler, P.A., Masson, D.D., Fisher, E.H., Hauton, C., Hühnerback, V., Le Bas, T.P., Wolff, G.A., 2011. A picture on the wall: innovative mapping reveals cold-water coral refuge in submarine canyon. PLos ONE 6, e28755. http:// dx.doi.org/10.1371/journal.pone.0028755.

Huvenne, V.A.I., Van Rooij, D., De Mol, B., Thierens, M., O'Donnell, R., Foubert, A., 2009b. Sediment dynamics and palaeo-environmental context at key stages in the challenger cold-water coral mound formation: clues from sediment deposits at the mound base. Deep-sea Research I 56, 2263-2280.

Kano, A., Ferdelman, T.G., Williams, T., Henriet, J.-P., Ishikawa, T., Kawagoe, N., Takashima, C., Kakizaki, Y., Abe, K., Sakai, S., Browning, E.L. Li, X., IODP Exp.307 Scientists, 2007. Age constraints on the origin and growth history of a deepwater coral mound in the northeast Atlantic drilled during integrated ocean drilling program expedition 307. Geology 35, 1051-1054.

Kennet, J.P., Srinivasan, M.S., 1983. Neogene Planktonic Foraminifera: a Phylogenetic Atlas. Hutchinson Ross, Stroudsburg, USA, p. 265.

Kiriakoulakis, K., Freiwald, A., Fisher, E., Wolff, G.A., 2007. Organic matter quality and supply to deep-water coral/mound systems of the NW European Continental Margin. International Journal of Earth Sciences 96, 159-170.

Kitamura, A., Kimoto, K., 2007. Eccentricity cycles shown by early Pleistocene planktonic foraminifers of the Omma Formation, Sea of Japan. Global and Planetary Change 55, 273-283.

Knutz, P.C., Zahn, R., Hall, I.R., 2007. Centennial-scale variability of the British Ice Sheet: implications for climate forcing and Atlantic meridional overturning circulation during the last deglaciation. Paleoceanography 22, PA1207. http:// dx.doi.org/10.1029/2006PA001298.

Laberg, J.S., Stoker, M.S., Dahlgren, K.I.T., de Haas, H., Haflidason, H., Hjelstuen, B.O., Nielsen, T., Shannon, P.M., Vorren, T.O., van Weering, T.C.E., Ceramicola, S., 2005 Cenozoic along slope processes and sedimentation on the NW European Atlantic margin. Marine and Petroleum Geology 22, 1069-1088.

Lawrence, K.T., Sosdian, S., White, H.E., Rosenthal, Y., 2010. North Atlantic climate evolution through the Plio-Pleistocene climate transitions. Earth and Planetary Science Letters 300, 329-342.

Lisiecki, L.E., Raymo, M.E. 2005. A Pliocene-Pleistocene stack of 57 globally distributed benthic $\delta^{18} \mathrm{O}$ records. Paleoceanography 20, PA1003. http:// dx.doi.org/10.1029/2004PA001071.

Lisiecki, L.E., Raymo, M.E., 2007. Plio-Pleistocene climate evolution: trends and transitions in glacial cycle dynamics. Quaternary Science Reviews 26, 56-69.

Liu, Z., Colin, C., Trentesaux, A., Blamart, D., Siani, G., Sicre, M.-A., 2004. Erosional history of the eastern Tibetan Plateau since 190 kyr ago: clay mineralogical and geochemical investigations from the southwestern South China Sea. Marine Geology 209, 1-18.

López Correa, M., Montagna, P., Joseph, N., Rüggeberg, A., Fietzke, J., Flögel, S., Dorschel, B., Goldstein, S.L., Wheeler, A., Freiwald, A., 2012. Preboreal onset of Norwegian cold-water coral growth beyond the Arctic Circle revealed by radiocarbon and U-series dating and neodymium isotopes. Quaternary Science Reviews 34, 24-43.

Lutringer, A., Blamart, D., Frank, N., Labeyrie, L., 2005. Paleotemperatures from deep-sea corals: scale effects. In: Freiwald, A., Roberts, J.M. (Eds.), Cold-water Corals and Ecosystems. Springer-Verlag, Berlin Heidelberg, pp. 1081-1096.

Marinoni, L., Setti, M., Salvi, C., Lopez-Galindo, A., 2008. Clay minerals in late Quaternary sediments from the south Chilean margin as indicators of provenance and palaeoclimate. Clay Minerals 43, 235-253.

Maslin, M.A., Li, X.S., Loutre, M.-F., Berger, A., 1998. The contribution of orbital forcing to the progressive intensification of Northern Hemisphere glaciation. Quaternary Science Reviews 17, 411-426.

McManus, J.F., Oppo, D.W., Cullen, J.L., 1999. A 0.5-million-year record of millennialscale climate variability in the North Atlantic. Science 283, 971-975.

Medina-Elizalde, M., Lea, D.W., 2010. Late Pliocene equatorial Pacific. Paleoceanography 25, PA2208. http://dx.doi.org/10.1029/2009PA001780.

Mienis, F., de Stigter, H.C., de Haas, H., van Weering, T.C.E., 2009a. Near-bed particle deposition and resuspension in a cold-water coral mound area at the Southwest Rockall Trough margin, NE Atlantic. Deep-sea Research I 56, 1026-1038.

Mienis, F., de Stigter, H.C., White, M., Duineveld, G., de Haas, H., van Weering, T.C.E. 2007. Hydrodynamic controls on cold-water coral growth and carbonatemound development at the SW and SE Rockall Trough Margin, NE Atlantic Ocean. Deep-sea Research I 54, 1655-1674.

Mienis, F., Duineveld, G., Davies, A.J., Ross, S.W., Seim, H., Bane, J., van Weering, T.C.E., 2012. The influence of near-bed hydrodynamic conditions on cold-water corals in the Viosca Knoll area, Gulf of Mexico. Deep-sea Research I $60,32-45$.

Mienis, F., van der Land, C., de Stigter, H.C., van de Vorstenbosch, M., de Haas, H., Richter, T., van Weering, T.C.E., 2009b. Sediment accumulation on a cold-water carbonate mound at the Southwest Rockall Trough margin. Marine Geology 265, 40-50.

Naafs, B.D.A., Stein, R., Hefter, J., Khélifi, N., De Schepper, S., Haug, G.H., 2010. Late Pliocene changes in the North Atlantic Current. Earth and Planetary Science Letters 298, 434-442.

New, A.L., Barnard, S., Herrmann, P., Molines, J.-M., 2001. On the origin and pathway of the saline inflow to the Nordic Seas: insights from models. Progress in Oceanography 48, 255-287.
Nie, J., King, J., Fang, X., 2008. Late Pliocene-early Pleistocene 100-ka problem. Geophysical Research Letters 35, L21606. http://dx.doi.org/10.1029/ 2008GL035265.

Paillard, D., Labeyrie, L., Yiou, P., 1996. Macintosh program performs time-series analysis. EOS (Transactions, American Geophysical Union) 77, 379.

Peck, V.L., Hall, I.R., Zahn, R., Grousset, F., Hemming, S.R., Scourse, J.D., 2007. The relationship of Heinrich events and their European precursors over the past 60 ka BP: a multi-proxy ice-rafted debris provenance study in the North East Atlantic. Quaternary Science Reviews 26, 862-875.

Petschick, R., 2000. MacDiff 4.2.5 Manual, p. 61.

Pirlet, H., Colin, C., Thierens, M., Latruwe, K., Van Rooij, D., Foubert, A., Frank, N. Blamart, D., Huvenne, V.A.I., Vanhaecke, F., Henriet, J.-P., 2011. The importance of the terrigenous fraction within a cold-water coral mound: a case study. Marine Geology 282, 13-25.

Pujol, C., Duprat, J., 1985. Quaternary and Pliocene planktonic foraminifers of the northeastern Atlantic (Goban Spur), deep sea drilling project Leg 80. In: Graciansky, P.C., de Poag, C.W., et al. (Eds.), 1985. Init. Repts. DSDP, vol. 80. U.S. Govt. Printing Office, Washington, pp. 683-723.

Raddatz, J., Rüggeberg, A., Margreth, S., Dullo, W.-C., IODP Exp. 307 Scientific Party, 2011. Paleoenvironmental reconstruction of Challenger Mound initiation in the Porcupine Seabight, NE Atlantic. Marine Geology 282, 79-90.

Raffi, I., Backman, J., Fornaciari, E., Pälike, H., Rio, D., Lourens, L., Hilgen, F., 2006. A review of calcareous nannofossil astrobiochronology encompassing the past 25 million years. Quaternary Science Reviews 25, 3113-3137.

Raymo, M.E., Ruddiman, W.F., Clement, B.M., 1986. Pliocene/Pleistocene paleoceanography of the North Atlantic at DSDP site 609. In: Ruddiman, W.F. Kidd, R.B., Thomas, E., et al. (Eds.), Initial Reports of the Deep Sea Drilling Project, 94. U.S. Govt. Printing Office, Washington, pp. 895-901.

Rice, A.L., Billet, D.S.M., Thurston, M.H., Lampitt, R.S., 1991. The institute of oceanographic sciences biological programme in the porcupine seabight: background and general introduction. Journal of the Marine Biological Association of the UK $71,281-310$.

Roberts, J.M., Wheeler, A.J., Freiwald, A., 2006. Reefs of the deep: the biology and geology of cold-water coral ecosystems. Science 312, 543-547.

Roberts, J.M., Wheeler, A.J., Freiwald, A., Cairns, S., 2009. Cold-water Corals. The Biology and Geology of Deep-sea Coral Habitats. Cambridge University Press, p. 334.

Ruddiman, W.F., Raymo, M.E., Martinson, D.G., Clement, B.M., Backman, J., 1989. Pleistocene evolution: northern hemisphere ice sheets and North Atlantic Ocean. Paleoceanography 4, 353-412.

Rüggeberg, A., Dullo, W.-C., Dorschel, B., Hebbeln, D., 2007. Environmental changes and growth history of a cold-water carbonate mound (Propeller Mound, Porcupine Seabight). International Journal of Earth Sciences 96, 57-72.

Rüggeberg, A., Fietzke, J., Liebetrau, V., Eisenhauer, A., Dullo, W.-C., Freiwald, A. 2008. Stable strontium isotopes $\left(\delta^{88} /{ }^{86} \mathrm{Sr}\right)$ in cold-water corals - a new proxy for reconstruction of intermediate ocean water temperature. Earth and Planetary Science Letters 269, 570-575.

Sakai, S., Kano, A., Abe, K., 2009. Origin, glacial-interglacial responses, and controlling factors of a cold-water coral mound in NE Atlantic. Paleoceanography 24, PA2213. http://dx.doi.org/10.1029/2008PA001695.

Sarnthein, M., Fenner, J., 1988. Global Wind-induced Change of Deep-sea Sediment Budgets, New Ocean Production and $\mathrm{CO}_{2}$ Reservoirs ca. 3.3-2.35 Ma BP. In: Philosophical Transactions of the Royal Society, London, vol. 318, pp. 487-504.

Sato, T., Kameo, K., 1996. Pliocene to Quaternary calcareous nannofossil biostratigraphy of the Arctic Ocean, with reference to late Pliocene glaciation. In: Proceedings of the Ocean Drilling Program, Scientific Results, vol. 151, pp. 39-59.

Sato, T., Yuguchi, S., Takayama, T., Kameo, K., 2004. Drastic change in the geographical distribution of the cold-water nannofossil Coccolithus pelagicus (Wallich) Schiller at $2.74 \mathrm{Ma}$ in the late Pliocene, with special reference to glaciation in the Arctic Ocean. Marine Micropaleontology 52, 181-193.

Schiebel, R., Schmuker, B., Alves, M., Hemleben, C., 2002. Tracking the recent and late Pleistocene Azores front by the distribution of planktic foraminifers. Journal of Marine Systems 37, 213-227.

Scourse, J.D., Haapaniemi, A.I., Colmenero-Hidalgo, E., Peck, V.L., Hall, I.R Austin, W.E.N., Knutz, P.C., Zahn, R., 2009. Growth, dynamics and deglaciation of the last British-Irish ice sheet: the deep-sea ice-rafted detritus record. Quaternary Science Reviews 28, 3066-3084.

Shackleton, N.J., Crowhurst, S., Hagelberg, T., Pisias, N.G., Schneider, D.A. 1995. A new late Neogene timescale: application to Leg 138 sites. In: Pisias, N.G. Mayer, L.A., Janecek, T.R., Palmer-Julson, A., van Andel, T.H. (Eds.). Proceedings of the Ocean Drilling Program, Scientific Results, vol. 138. Ocean Drilling Program, College Station, TX, pp. 73-101. http://dx.doi.org/10.2973/ odp.proc.sr.138.106.1995.

Shannon, P.M., McDonnell, A., Bailey, W.R., 2007. The evolution of the Porcupine and Rockall basins, offshore Ireland: the geological template for carbonate mound development. International Journal of Earth Sciences 96, 21-35.

Sherwood, O.A., Heikoop, J.M., Sinclair, D.J., Scott, D.B., Risk, M., Shearer, C., AzetsuScott, K., 2005. Skeletal Mg/Ca in Primnoa resedaeformis: relationship to temperature? In: Freiwald, A., Roberts, J.M. (Eds.), Cold-water Corals and Ecosystems. Springer-Verlag, Berlin Heidelberg, pp. 1061-1079.

Sosdian, S., Rosenthal, Y., 2009. Deep-sea temperature and ice volume changes across the Pliocene-Pleistocene climate transitions. Science 325, 306-309. 
Stein, R., Hefter, J., Grützner, J., Voelker, A., Naafs, B.D.A., 2009. Variability of surface water characteristics and Heinrich-like events in the Pleistocene midlatitude North Atlantic Ocean: biomarker and XRD records from IODP site U1313 (MIS 16-9). Paleoceanography 24, PA2203. http://dx.doi.org/10.1029/2008PA001639.

Stoker, M.S., Leslie, A.B., Scott, W.D., Briden, J.C., Hine, N.M., Harland, R., Wilkinson, I.P., Evans, D., Ardus, D.A., 1994. A record of late Cenozoic stratigraphy, sedimentation and climate change from the Hebrides Slope, NE Atlantic Ocean. Journal of the Geological Society, London 151, 235-249.

Stoker, M.S., Praeg, D., Hjelstuen, B.O., Laberg, J.S., Nielsen, T., Shannon, P.M., 2005 Neogene stratigraphy and the sedimentary and oceanographic development of the NW European Atlantic margin. Marine and Petroleum Geology 22, 977-1005.

Thierens, M., Pirlet, H., Colin, C., Latruwe, K., Vanhaecke, F., Lee, J.R., Stuut, J.-B. Titschack, J., Huvenne, V A.I, Dorschel, B., Wheeler A J. Henriet, J.-P. 2012. Icerafting from the British-Irish ice sheet since the earliest Pleistocene (2.6 million years ago): implications for long-term mid-latitudinal ice-sheet growth in the North Atlantic region. Quaternary Science Reviews 44, 229-240.

Thierens, M. Titschack, J., Dorschel, B., Huvenne, V.A.I. Wheeler, AJ., Stuut, J.-B, O'Donnell, R., 2010. The 2.6 Ma depositional sequence from the challenger coldwater coral carbonate mound (IODP Exp. 307): sediment contributors and hydrodynamic palaeo-environments. Marine Geology 271, 260-277.

Thomson, D.J., 1982. Spectrum estimation and harmonic analysis. Proceedings of the IEEE 70, 1055-1096.

Titschack, J., Thierens, M., Dorschel, B., Schulbert, C., Freiwald, A., Kano, A., Takashima, C., Kawagoe, N., Li, X., IODP Exp. 307 Scientific Party, 2009. Carbonate budget of a cold-water coral mound (Challenger Mound, IODP Exp. 307). Marine Geology 259, 36-46.

Torrence, C., Compo, G.P., 1998. A practical guide to wavelet analysis. Bulletin of the American Meteorological Society 79, 61-78.

van Kreveld, S.A., Knappertsbusch, M., Ottens, J., Ganssen, G.M., van Hinte, J.E., 1996. Biogenic carbonate and ice-rafted debris (Heinrich layer) accumulation in deep-sea sediments from a Northeast Atlantic piston core. Marine Geology 131, 21-46.

Van Rooij, D., Blamart, D., Richter, T., Wheeler, A., Kozachenko, M., Henriet, J.P., 2007. Quaternary sediment dynamics in the Belgica mound province, Porcupine Seabight: ice-rafting events and contour current processes. International Journal of Earth Sciences 96, 121-140.

Van Rooij, D., De Mol, B., Huvenne, V.A.I., Ivanov, M., Henriet, J.P., 2003. Seismic evidence of current-controlled sedimentation in the Belgica Mound province, upper Porcupine slope, southwest of Ireland. Marine Geology 195, 31-53.
Van Rooij, D., Huvenne, V.A.I., Blamart, D., Henriet, J.-P., Wheeler, A.J., de Haas, H., 2009. The Enya mounds: a lost mound-drift competition. International Journal of Earth Sciences 98, 849-863.

Vogt, C. Knies, J. 2008. Sediment dynamics in the Eurasian Arctic Ocean during the last deglaciation - The clay mineral group smectite perspective. Marine $\mathrm{Ge}$ ology 250, 211-222.

Watkins, D.K., Bergen, J.A., 2003. Late Albian adaptive radiation in the calcareous nannofossil genus Effellithus. Micropaleontology 49, 231-252.

Weaver, P.E., Clement, B.M., 1986. Synchroneity of Pliocene planktonic foraminiferal datums in the North Atlantic. Marine Micropaleontology 10, 295-307.

Wheeler, A.J., Beyer, A., Freiwald, A., de Haas, H., Huvenne, V.A.I., Kozachenko, M., Olu- Le Roy, K., Opderbecke, J., 2007. Morphology and environment of coldwater coral carbonate mounds on the NW European margin. International Journal of Earth Sciences 96, 37-56.

Wheeler, A.J., Kozachenko, M., Masson, D.D., Huvenne, V.A.I., 2008. Influence of benthic sediment transport on cold-water coral bank morphology and growth: the example of the Darwin Mounds, north-east Atlantic. Sedimentology 55, 1875-1887.

White, M., 2007. Benthic dynamics at the carbonate mound regions of the Porcupine Sea Bight continental margin. International Journal of Earth Sciences 96, $1-9$.

White, M., Dorschel, B., 2010. The importance of the permanent thermocline to the cold water coral carbonate mound distribution in the NE Atlantic. Earth and Planetary Science Letters 296, 395-402.

White, M., Roberts, J.M., van Weering, T.C.E., 2007. Do bottom-intensified diurnal tidal currents shape the alignment of carbonate mounds in the NE Atlantic? Geo-Marine Letters 27, 391-397.

Wienberg, C., Frank, N., Mertens, K., Stuut, J.-B., Marchant, M., Fietzke, J., Mienis, F., Hebbeln, D., 2010. Glacial cold-water coral growth in the Gulf of Cádiz: Implications of increased palaeo-productivity. Earth and Planetary Science Letters 298, 405-416.

Zimmerman, H.B. Shackleton, N.J., Backman, J., Kent, D.V., Baldauf, J.G., Kaltenback, A.J., Morton, A.C., 1984. History of Plio-Pleistocene climate in the northeastern Atlantic, deep sea drilling project Hole 552A. In: Roberts, D.G., Schnitker, D. (Eds.). Initial Reports of the Deep Sea Drilling Project, vol. 81. U.S. Govt. Printing Office, Washington.

Ziveri, P., Baumann, K.-H., Boeckel, B., Bollmann, J., Young, J.R., 2004. Biogeography of selected Holocene coccoliths in the Atlantic Ocean. In: Thierstein, H.R., Young, J.R. (Eds.), Coccolithophores From Molecular Processes to Global Impact. Springer, Berlin, pp. 403-428. 